Article

\title{
Performance Enhancement of Micro Grid System with SMES Storage System Based on Mine Blast Optimization Algorithm
}

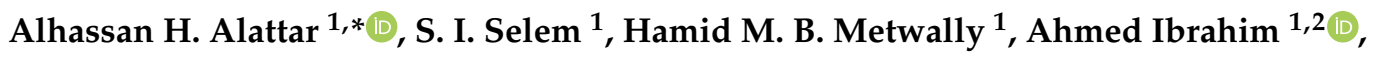 \\ Raef Aboelsaud ${ }^{1,2}$, Mohamed A. Tolba ${ }^{3,4}$ and Ali M. El-Rifaie ${ }^{5, * D}$ \\ 1 Department of Electrical Power and Machines, Zagazig University, Zagazig 44519, Egypt \\ 2 Department of Electric power systems, School of Energy and Power Engineering, National Research Tomsk \\ Polytechnic University, Tomsk 634050, Russia \\ 3 Nuclear Researches Center, Egyptian Atomic Energy Authority (EAEA), Cairo 11787, Egypt \\ 4 Electrical Power System Department, Moscow Power Engineering Institute, Moscow 111250, Russia \\ 5 College of Engineering and Technology, American University of Middle East, Eqaila 15453, Kuwait \\ * Correspondence: alhassanalattar@yahoo.com (A.H.A.); ali.el-refaie@aum.edu.kW (A.M.E.-R.); \\ Tel.: +20-1117478740 (A.H.A.); +96-551510805 (A.M.E.-R.)
}

Received: 7 July 2019; Accepted: 7 August 2019; Published: 13 August 2019

\begin{abstract}
Frequency control represents a critically significant issue for the enhancement of the dynamic performance of isolated micro grids. The micro grid system studied here was a wind-diesel system. A new and robust optimization technique called the mine blast algorithm (MBA) was designed for tuning the PID (proportional-integral-differential) gains of the blade pitch controller of the wind turbine side and the gains of the superconducting magnetic energy storage (SMES) controller. SMES was implemented to release and absorb active power quickly in order to achieve a balance between generation and load power, and thereby control system frequency. The minimization of frequency and output wind power deviations were considered as objective functions for the PID controller of the wind turbine, and the diesel frequency and power deviations were used as objective functions for optimizing the SMES controller gains. Different case studies were considered by applying disturbances in input wind, load power, and wind gust, and sensitivity analysis was conducted by applying harsh conditions with varying fluid coupling parameter of the wind-diesel hybrid system. The proposed MBA-SMES was compared with MBA (tuned PID pitch controller) and classical PI control systems in the Matlab environment. Simulation results showed that the MBA-SMES scheme damped the oscillations in the system output responses and improved the system performance by reducing the overshoot by $75 \%$ and $36 \%$ from classical and MBA-based systems, respectively, reduced the settling time by $45 \%$ compared to other systems, and set the final steady-state error of the frequency deviation to zero compared to other systems. The proposed scheme was extremely robust to disturbances and parameter variations.
\end{abstract}

Keywords: wind turbine; diesel generator; SMES; pitch control; mine blast algorithm

\section{Introduction}

Remote areas mainly depend on diesel generator units to meet their load demand. In addition, some critical loads as nuclear research reactors and others need effective isolation away from any interruptions or quality problems that might take place in the distribution network. Due to the cost, transportation of fuels, and the emission of undesirable gases from diesel generator engines [1], renewable resources are the solution for supplying remote areas' demand. The disadvantages of the photovoltaic systems are their low conversion efficiency with high cost compared to wind power 
systems [2]. Wind power has many advantages, as it is clean, produces no air pollution, and is a renewable natural resource.

Diesel generators can be operated in conjunction with wind systems in isolated communities, and act as a standby power source to share load demand in cases of disturbance and wind energy shortage. Diesel generators are not efficient when operating at load factor below $40 \%-50 \%$ of their nominal power [3]. Diesel-wind systems are famous hybrid power systems. These systems help to reduce fuel and generation costs. In addition, the emissions of undesirable gases can be reduced and minimized [4]. Also, the combination adds a great advantage to the system, where the required cost of connection between the national grid to remote regions is high $[5,6]$.

Wind-diesel systems enhance system reliability [7] because the diesel generators generate power equal to the difference between wind and load power [8]. According to the wind power penetration ratio, there are three types of hybrid system: low, medium, and high penetration [9] (i.e., the ratio of annual wind energy to annual demand energy). If energy penetration is below $20 \%$, the wind-diesel system is considered as low penetration. If the ratio falls between $20 \%$ and $50 \%$, the system is classified as medium energy penetration. In high wind penetration, if the system is able to disconnect the diesel generator during operation.

One objective of power quality in micro grid systems is to supply the required load demand of isolated communities with the required power and voltage and constant frequency within the specified standard allowable limits. It is known that wind turbine power has a strong relation with wind speed; wind energy varies quickly from one moment to another. Also, the load demands of isolated communities change frequently, which affects the system frequency. This frequency change significantly decreases power quality and system reliability. Controlling system frequency is based on controlling the active power load-generation mismatch power. Wind turbine blade pitch control is robust, and there are effective approaches to control wind turbines to ensure a constant supply of wind energy and achieve balance in generation and demand power.

Many researchers have proposed various techniques for wind turbine blade pitch control, as follows. A pitch controller was proposed for the wind turbine and the governor in the diesel unit to damp frequency fluctuations in $[10,11]$. A proportional-integral (PI) controller was proposed in $[12,13]$. Optimization of the wind pitch controller for frequency control was designed [14-17] based on the genetic algorithm. A fuzzy logic controller was proposed for controlling the hybrid system [18-20], and a second type was based on artificial neural networks [21]. The particle swarm algorithm (PSO) is applied in [22-24]. Genetic algorithm and PSO are used in [25,26]. The bee colony optimization algorithm (BCO) is introduced in [27]. Bacterial forging optimization (BFO) is designed in [28]. $\mathrm{H}_{\infty}$ control has been applied to control the pitch angle, as in $[29,30]$. The differential evaluation algorithm technique is used for tuning the PI pitch controller in [31,32]. The modified harmony search algorithm (MHSA) technique is used to tune the PI controller in [33]. The imperialist competitive algorithm is designed in [34]. A relay-based technique is proposed in [35]. Gases Brownian motion optimization (GBMO) is proposed in [36]. Distributed model predictive (DMP) control is used by the authors in [37]. The modified bat-inspired algorithm (MBIA) is applied in [38].

At present, energy storage units are used with renewable sources to act as backup units and store power when generated power is greater than the load power and discharge their power to the system in peak periods of load demand. This action reduces levels of fluctuations. So, energy storage maintains acceptable limits of the system's frequency [39,40]. One of the most efficient storage systems is superconducting magnetic energy storage (SMES). SMES stores energy by direct currents passing through a superconducting coil. This current develops magnetic flux. Electric energy can be stored as circulating current; it can be released or delivered instantaneously from the SMES unit from fractions of a second to hours [41]. The main advantage of SMES is its ability to release large amounts of power within a small amount of time (fraction of cycle) [42], and then completely recharge in few minutes. Its efficiency can reach $98 \%$ or more. The switching time between charging and discharging is about $17 \mathrm{~ms}$. It has a quick and high-power response, and moreover it is economical; the estimated 
lifetime of SMES systems is about 20 years [43]. This paper presents a robust control methodology for a wind-diesel-SMES system. Two controllers were designed to enhance the system performance. The first PID (proportional-integral-differential) controller was designed to control the blade pitch system to maintain constant wind energy supply and thereby control the system frequency. Then, SMES is implemented to quickly absorb the active power fluctuations.

The mine blast algorithm (MBA) is a population-based algorithm, and it was first introduced in [44-46] as an offline algorithm. MBA was proposed and designed to solve complex control tasks. It is used in $[44,46]$ to solve truss structure problems; results clearly illustrated the effectiveness of the method for solving problems of many design parameters and criteria. In addition, it has a fast rate of convergence to reach the optimal (best) solution and also has low burden (function computational evaluations), verifying MBA's potential to solve complicated problems compared to other systems such as genetic algorithm and PSO. In [45], a comparative study showed that MBA was more effective than other recognized optimization algorithms in terms of computational effort and function value for sixteen engineering problems. It was applied in [47] to obtain the optimal sizing for photovoltaic (PV) fuel cells and wind turbines to supply a certain load; MBA saved $24.82 \%, 11.5576 \%$, and $8.95 \%$ in the yearly cost compared with PSO, BCO, and cuckoo search algorithm, respectively. MBA was used to find the best design networks [48] of water distribution systems for minimizing the network construction costs. The cost was 5\% lower (reduced from $€ 2.17$ to $€ 2.064$ million) than a conventional system. It has also been used to obtain the maximum power point of partially shaded photovoltaic systems [49], and results showed that the MBA tracker was more reliable and efficient compared to adaptive neuro-fuzzy, fuzzy logic, and PSO-based systems. In [50], optimal gain scheduling of the voltage source converters in high-voltage direct current systems was obtained to ensure the desired dynamic behavior and stability improvement. Load frequency control was designed based on a PID controller tuned by MBA for multi-interconnected areas [51], the system was robust compared to antlion, artificial bee colony, hybrid differential evolution PSO, and hybrid PSO pattern search optimizers [52]. MBA was applied to a variable-speed wind generator to evaluate the optimal parameters of the rotor current PI controller for setting rotor current close to the desired reference one and tracking the reference system frequency. Based on the above discussion, it can be said that MBA is a simple robust technique that converges quickly and requires few design control parameters.

This paper is subdivided as follows. The system model is discussed and given in Section 2. In Section 3 the design of the controller with an objective fitness function is provided. The MBA algorithm is detailed in Section 4. Results and discussion are explained in Section 5, and the conclusions are discussed in Section 6.

\section{System Modeling}

\subsection{Basic Wind-Diesel System}

The basic diagram of the hybrid wind-diesel system $[31,53,54]$ is shown in Figure 1 . The system consists of a $200 \mathrm{~kW}$ diesel generator controlled by a speed governor system and a $150 \mathrm{~kW}$ wind turbine generator controlled by a blade pitch controller. The diesel generator, wind generator, and power system parameters under study are listed $[31,53,54]$ in Appendix A in Table A1. The wind turbine and diesel generators' transfer functions and model are completely illustrated in $[31,53,54]$. 


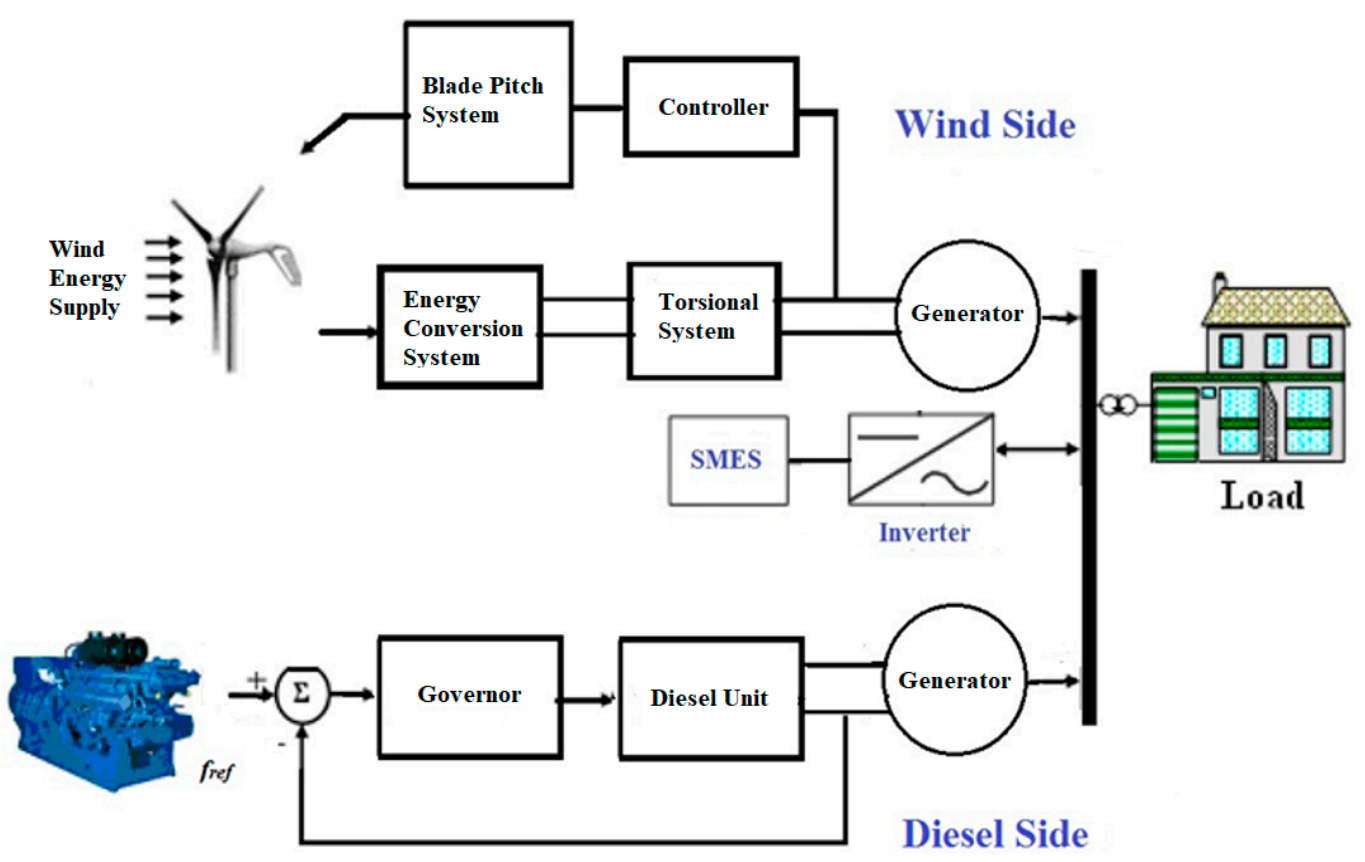

Figure 1. Basic wind-diesel-SMES (superconducting magnetic energy storage) system.

The inertia of the diesel generators and load are lumped together. The diesel governor and throttle compare the system speed (frequency) to a reference speed and compensate for speed error by changing the fuel rate.

\subsection{Blade Pitch System}

As mentioned in [55], pitch occurs when there is a variation of the wind speed. Thus, pitch angle control of the blades is a must for ensuring the continuity of energy production by reducing the turbine output power to its nominal level (power control) and protecting the turbine devices from extra high power (safety constraints) during high wind speed. In real systems, this control is basically based on using an anemometer on the nacelle to measure the wind speed and its direction. In the proposed study, the anemometer is simulated by an input variation in wind input power [53], as any variation in the wind speed will be reflected into a variation in the turbine input power $\left(\Delta P_{w}\right)$.

The blade angle of the wind turbine is controlled by the microprocessor-based controller. Pitch angle can be controlled according to power speed curve shown in Figure 2. The pitch control system can be illustrated by subdividing the power speed curve into four regions [29]:

\section{(1) Below cut-in speed}

When the wind speed is less than the cut in speed ( $3-3.5 \mathrm{~m} / \mathrm{s}$ according to the wind turbine design), the value of the pitch angle must be increased to the maximum value, as the turbine output power is the smallest at this point. $P_{w t g}=0 \mathrm{~kW}$, so the pitch angle is fixed at $90^{\circ}$ as the turbine output is the smallest.

(2) From cut-in to speed at which rated power occurs (partial load region)

When the wind speed is between cut in and the speed at which rated power can be obtained, the value of the pitch angle must be set at value at which the maximum power can be captured from the wind. The range of $P_{w t g}$ is from 0 to $150 \mathrm{~kW}$, so the pitch angle is fixed at $10^{\circ}$, as energy is largest at this angle. 
(3) From speed at which the rated power is captured to cut-out

When the wind speed is higher than the rated speed, the power is higher than the nominal value, so the value of the pitch angle must be increased to reduce the turbine output power. Thus, the rated electric power can still be produced. $P_{w t g}=150 \mathrm{~kW}$, so the pitch angle is varied from $10^{\circ}$ to $90^{\circ}$.

(4) Above cut-out speed

When the wind speed is higher than its cut-out value, the value of the pitch angle must be increased to disconnect the wind turbine and set the output power to zero. $P_{w t g}=0 \mathrm{~kW}$, so the pitch angle is fixed at $90^{\circ}$ for safety.

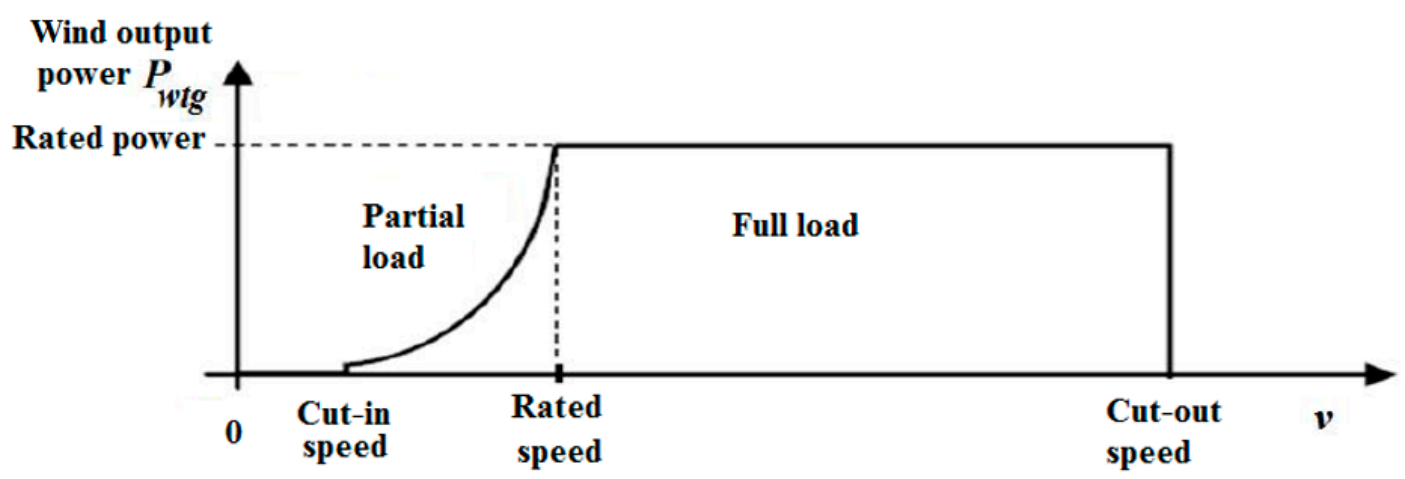

Figure 2. Output power vs. wind speed characteristic.

The pitch system consists of a hydraulic pitch actuator for changing the angle of the blades, a PID controller that is altered by the error signal between the power set point $\left(P_{\max }\right)$ and the actual power $P_{\text {wtg. }}$. It can be modeled as in $[31,53,54]$. The power reference set point $\left(P_{\max }\right)$ can be controlled and adjusted from 25 to $150 \mathrm{~kW}$. When wind turbine $P_{\text {wtg }}$ provides less power than the reference power, there will be an error difference which alters the hydraulic actuator system. Then, pitch angle control becomes active and compares the generated power to $P_{\max }$ (the power set point) and compensates for power error by changing the blade angle and thus the mechanical power; this error sets the blades' angle to $10^{\circ}$ (fully feathered position at shutdown). When the power output exceeds $P_{\max }$, the pitch control will be active to control for constant $P_{\max }$ power output. The specified transfer function programmed in the microprocessor controller contains a proportional-integral coefficient-differential controller.

\subsection{Superconducting Magnetic Energy Storage (SMES) System}

The SMES system can be modeled by a first-order function [56] with a time constant $T_{s m}=0.03 \mathrm{~s}$. The controller was designed as first-order compensator with a single feedback input signal, diesel frequency deviation, $\Delta f_{d}$.

The system block diagram is illustrated in Figure 3 [31,53,54].

The wind-diesel dynamic behavior is modeled by the set of differential equations represented in state space as follows:

$$
\begin{gathered}
X^{\bullet}=A X+B U, \\
Y=C X+D U,
\end{gathered}
$$

where $X$ is the system state variables, it is a vector of tenth order whose elements are illustrated in Figure 3. $U$ is the system control input. $Y$ is the system output vector. $A, B, C$, and $D$ are the coefficient matrices of the hybrid system.

$$
\begin{gathered}
U=\left[\Delta P_{w} \Delta P_{\text {load }}\right], \\
Y=\left[\Delta f_{w} \Delta f_{d} \Delta P_{d} \Delta P_{w t g} \Delta P_{\text {smes }}\right],
\end{gathered}
$$

where $\Delta P_{w}$ and $\Delta P_{\text {load }}$ are the changes in wind and load power; 
$\Delta f_{w}$ and $\Delta f_{d}$ are the change in wind and diesel frequency;

$\Delta P_{d}$ is the deviation in diesel power;

$\Delta P_{\text {wtg }}$ is the deviation in wind power; and

$\Delta P_{\text {smes }}$ is the deviation in SMES power.

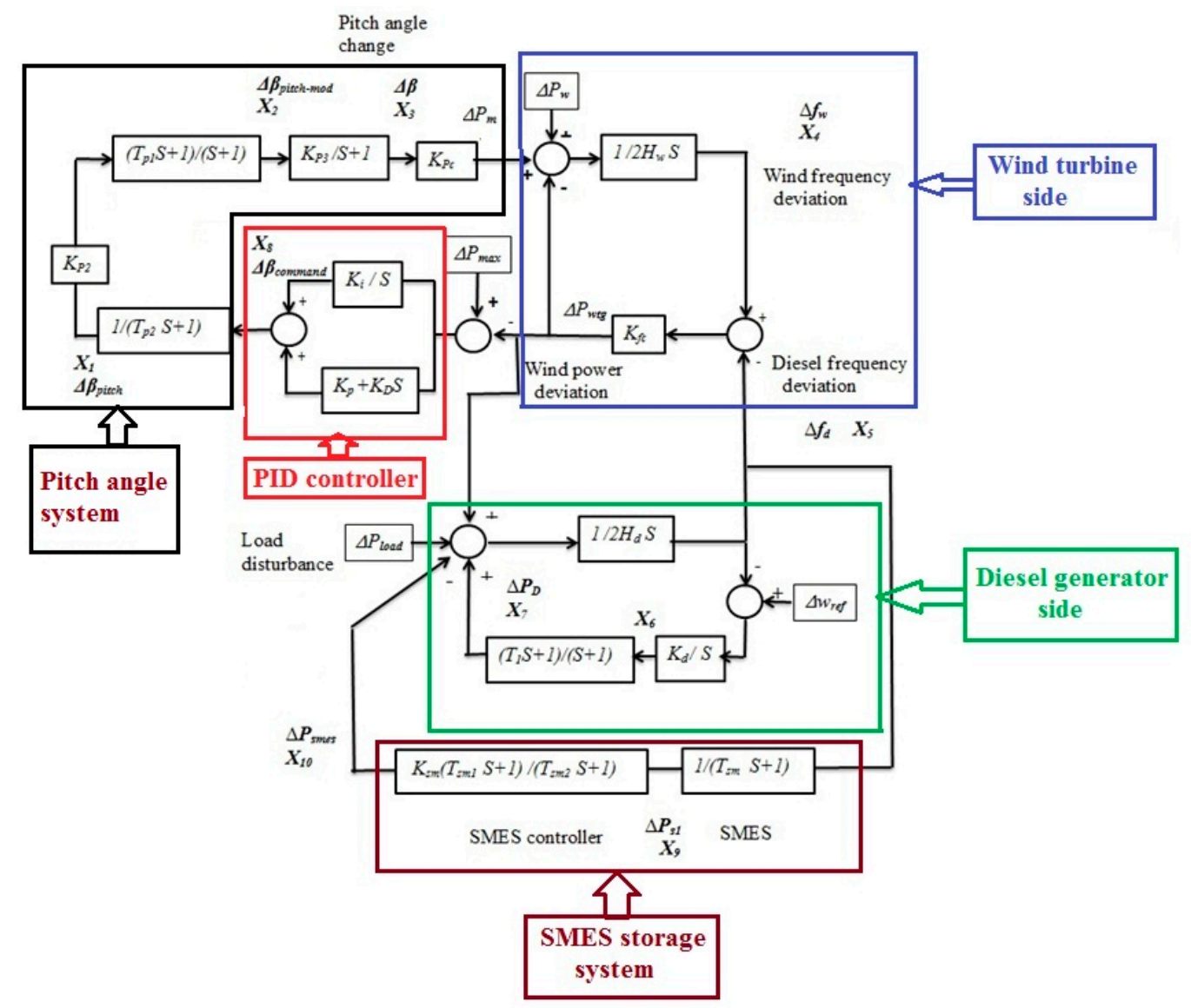

Figure 3. Hybrid wind-diesel block diagram system. PID: proportional-integral-differential.

\section{Control System and Objective Fitness Function}

At present, PID controllers are one of the most used industrial controllers, due to their robustness and simplicity to be understood. These systems can be designed in various structures (e.g., PID and PI) to control the wind turbine pitch angle for achieving superior dynamic performance of the wind-diesel system. In this paper, a PID controller was selected for controlling the pitch angle. The control input to the pitch actuator is formed as:

$$
U_{1}(t)=K_{p} \cdot A C E(t)+K_{I} \int_{0}^{t} A C E(t) d t+K_{D} \frac{d A C E(t)}{d t}
$$

where $A C E$ is the area control error, and $A C E(t)=\left(\Delta P_{\max }-\Delta P_{\text {wotg }}\right)$.

$K_{p}, K_{I}$, and $K_{D}$ are the proportional, integral, and derivative gains. If the turbine power $P_{w t g}=P_{\max }$ then $\Delta P_{\max }=0$. As the reference speed $w_{r e f}$ is constant for the diesel generator, then the reference speed change $\Delta w_{r e f}=0$. The system parameters including gains and time constants are listed in Appendix A. The objective function is formulated in the algorithm based on the required constraints and specifications. The performance index is the integral of absolute error (IAE) and it is used as a 
fitness function to find the optimal values for controllers. Thus, the objective fitness function can be rewritten as:

$$
J_{1}=\int_{0}^{t}\left(\left|\Delta P_{w t g}\right|+\left|\Delta f_{w}\right|\right) d t .
$$

Based on Equation (6), the problem is formulated as:

Minimize $J_{1}$, subject to,

$$
\begin{aligned}
K_{p}{ }^{\min } & \leq K_{p} \leq K_{p}{ }^{\max } \\
K_{I}{ }^{\min } & \leq K_{I} \leq K_{I}^{\max } \\
K_{D}{ }^{\min } & \leq K_{D} \leq K_{D}^{\max }
\end{aligned}
$$

The range selected in the algorithm for $K_{p}, K_{I}$, and $K_{D}$ is from 0 to 120 .

Also, the MBA system is used to minimize the SMES controller based on the following objective function:

$$
J_{2}=\int_{0}^{t}\left(\left|\Delta P_{D}\right|+\left|\Delta f_{d}\right|\right) d t
$$

subject to:

$$
\begin{aligned}
& K_{s m}{ }^{\min } \leq K_{s m} \leq K_{s m}{ }^{\max } \\
& T_{s m 1}{ }^{\min } \leq T_{s m 1} \leq T_{s m 1}{ }^{\max } \\
& T_{s m 2}{ }^{\text {min }} \leq T_{s m 2} \leq T_{s m 2}{ }^{\text {max }}
\end{aligned}
$$

where the ranges of SMES gain and time constants $\left(K_{s m}, T_{s m 1}\right.$, and $\left.T_{s m 2}\right)$ are [10-40], [0.1-2], and [0.01-0.1], respectively.

\section{Mine Blast Algorithm}

\subsection{Algorithm Basic Concept}

The main idea is based on mine explosion, where the shrapnel pieces collide with mine bombs, resulting in their explosion. Assume that the field has bombs with different explosion powers and sizes planted underground, and the aim is to find mine locations and clear them. The one that has the most explosive and dominant effect at point $x^{*}$ (optimal point) has the greatest fitness function. When a mine bomb explodes, the shrapnel pieces spread and the fitness $f(x)$ of each piece is evaluated and calculated. The existence of more explosive mines is indicated by their causalities. Each shrapnel piece collides with other bombs, leading to the explosion of the remaining mines. This collision leads to finding the most explosive and dominant mine.

\subsection{Proposed Method}

The MBA algorithm [45] chooses the initial point(s) randomly using the upper and lower limits. The first shot point is defined by $X_{0}^{f}$. The superscript $f$ represents the first shot point $(f=1,2,3,4 \ldots)$. The initial population $\left(N_{p o p}\right)$ produces a number of shrapnel pieces (individuals), and then the algorithm creates $X_{0}$ randomly as follows:

$$
X_{0}=l b+\text { rand } \times(u b-l b),
$$

where $X_{0}, u b$ and $l b$ are the first shot point and gain's upper and lower state limits, respectively, and rand is a randomly generated number.

The current location $X_{1}$ of a mine bomb is given by the following equation:

$$
X_{1}=\left\{X_{m}\right\} m=1,2,3, \ldots, N_{d}
$$


and the new location $X_{n+1}$ is:

$$
X_{n+1}^{f}=X_{e(n+1)}^{f}+\exp \left(-\sqrt{\left.\frac{m_{n+1}^{f}}{d_{n+1}^{f}}\right)} X_{n}^{f}, n=0,1,2, \ldots,\right.
$$

where $X_{n+1}^{f}, d_{n+1}^{f}$ are the location and distance of the exploded mine bomb. $m_{n+1}^{f}$ is the direction of the shrapnel. The mine location $X_{e(n+1)}^{f}$ is given as:

$$
X_{e(n+1)}^{f}=d_{e}^{f} \times \operatorname{rand} \times \cos (\theta), n=0,1,2, \ldots,
$$

where $\theta$ is the angle of shrapnel pieces, and it equals to $360 / N_{s}$. The algorithm explores the search space in $360^{\circ}$ in every iteration based on $\theta$ and $d_{n}^{f}$ to get the optimal solution. The distance $d_{n+1}^{f}$ and the direction $m_{n+1}^{f}$ of shrapnel pieces are given as:

$$
\begin{gathered}
d_{n+1}^{f}=\sqrt{\left(X_{n+1}^{f}-X_{n}^{f}\right)^{2}+\left(F_{n+1}^{f}-F_{n}^{f}\right)^{2}} n=0,1,2, \ldots, \\
m_{n+1}^{f}=\frac{\left(F_{n+1}^{f}-F_{n}^{f}\right)}{\left(X_{n+1}^{f}-X_{n}^{f}\right)} n=0,1,2, \ldots,
\end{gathered}
$$

where $\left(X_{n}^{f}\right)$ is the previous solutions and $F$ is the fitness function value for $X$. The algorithm sets the initial distance $d_{0}$ of shrapnel as $d_{0}=(u b-l b)$. The proposed algorithm searches within the initial distance range $L B\left\langle d_{0}\langle U B\right.$. The exploration factor $(\mu)$ is introduced, and if $\mu$ is higher than $K$, the exploration process starts. The exploration equations are:

$$
\begin{gathered}
d_{(n+1)}^{f}=d_{e}^{f} \times(\mid \text { rand } n \mid)^{2} n=0,1,2, \ldots, \\
X_{e(n+1)}^{f}=d_{n+1}^{f} \times \cos (\theta), n=0,1,2, \ldots
\end{gathered}
$$

Using $\mu$, the shrapnel piece distance is modified using Equation (14). The value of $\mu$ determines the process intensity. Then, the value of $\mu$ is set to a high value to search in more regions. The initial distance $d_{0}^{f}$ is reduced. This reduction allows the algorithm to obtain the optimal solution. In general, the reduction in $d_{n}^{f}$ is given as:

$$
d_{n}^{f}=\frac{d_{n-1}^{f}}{\exp (K / \alpha)}, n=0,1,2, \ldots,
$$

where $K$ and $\alpha$ are the iteration number and reduction factor. The steps of MBA are summarized [45] and its flowchart is illustrated in Figure 4. 


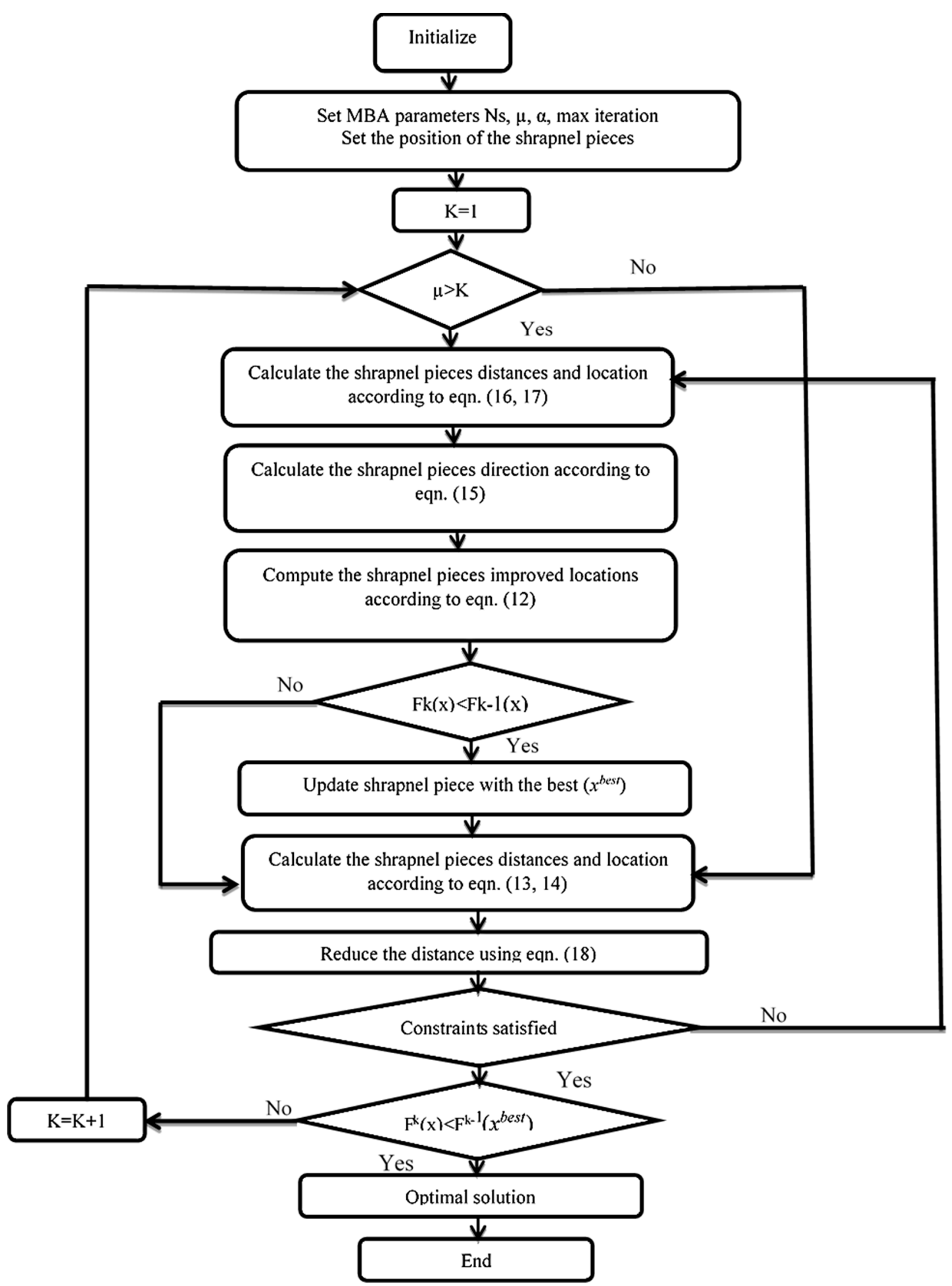

Figure 4. Flow chart of the mine blast algorithm (MBA).

\section{Simulation Results}

Three systems are designed in this paper based on the Matlab environment, and they can be defined as:

(1) Classical PI controller:

The blade pitch controller of the hybrid wind-diesel system is not tuned.

(2) MBA system: 
The blade pitch controller of the hybrid wind-diesel system is tuned based on the MBA algorithm. (3) MBA-SMES:

The blade pitch and SMES controllers of the hybrid wind-diesel-SMES system are tuned based on the MBA algorithm. The three systems were designed and compared.

Five case studies were designed and investigated. The first case was studied based on considering the input wind power disturbance only in order to show the effect of wind speed variation (simulated in the change of input wind power). The second case was studied by considering both changes in wind and load input powers, to show the effect of wind speed and load demand variations. In third case, the hybrid systems were subjected to (random wind input power) wind gust. The fourth case was done by applying harsh operating conditions including disturbances in input wind, load power, and fluid coupling parameter variation. Finally, a detailed sensitivity analysis was made based on fluid coupling change from $-30 \%$ to $30 \%$ of its nominal value. These case studies are discussed to show the effectiveness and robustness of the MBA-SMES scheme. The wind, diesel, and SMES data are defined in Table A1.

\subsection{Case 1}

A step increase of the wind power input $25 \%$ (system base of $350 \mathrm{~kW}$ ) was applied to the system. Figure 5 shows the frequency and power deviations for both diesel and wind generators, including the diesel frequency deviation. In the case of the classical PI controller and as shown in Figure 5a, the maximum overshoot (M.O) of wind frequency deviation was large $(0.0217 \mathrm{~Hz})$ and took a longer time $(2.609 \mathrm{~s})$, reaching steady state in approximately $15 \mathrm{~s}$. This indicates that the wind pitch system and the diesel governor did not work well. Contrarily, MBA and MBA-SMES controllers have the ability to reduce frequency deviation significantly by reducing the peak overshoot and settling time of the system response. The system performance parameters are listed in Table 1, and the MBA-SMES maximum overshoot was about $0.00559 \mathrm{~Hz}$, about 0.25 of classical and 0.63 of MBA systems, reaching its peak value (T.O.S) in $1.346 \mathrm{~s}$ (approximately 0.5 of classical and 0.64 of MBA systems) and its rise time (R.T) was about $0.00551 \mathrm{~s}$ and its settling time (S.T) was $6.217 \mathrm{~s}$ ( 0.007 of classical and 0.18 of MBA systems). As shown in Figure 5a, it is clear that the MBA-SMES system steady-state error (ess) reached zero compared to the MBA system (Hz) and classical system. Figure $5 b$ and Table 2 illustrate the diesel frequency response; the proposed system reduced the max overshoot to $0.00113 \mathrm{~Hz}(0.0035$ of classical and 0.0022 of MBA systems) in $1.56472 \mathrm{~s}$ ( 0.8148 of classical and 0.6875 of MBA systems), the rise time was about $4.23 \times 10^{-06} \mathrm{~s}(0.0988$ of classical and 0.18 of MBA systems $)$ and the settling time was $12.915 \mathrm{~s}$ ( 0.8037 of classical and 0.8783 of MBA systems).

Figure $5 c$ shows the diesel power deviations of the three systems with the SMES power deviation of the proposed MBA-SMES system. The SMES unit responded to system disturbances in order to damp the power oscillations rapidly. The diesel power deviation's performance parameters are listed in Table 3. In addition, Figure $5 \mathrm{~d}$ illustrates the wind output power deviations of the three systems. The difference of output power reference of wind turbine was set to zero (pu kW). For the classical system, the blade pitch system set the output power deviation to $25 \%$ due to the input disturbance, and then this controller did not work well. On the other hand, the proposed system based on MBA-SMES damped the output power oscillations in a very short time and their blade pitch controller set the output power deviation to zero (pu kW) by setting the M.O to $0.07923 \mathrm{~Hz}(0.0827$ of classical and 0.2704 of MBA systems) and the S.T to $6.412 \mathrm{~s}$ ( 0.4993 of classical and 0.558 of MBA systems). MBA with the SMES unit enhanced the performance of the system as listed in Table 4. 


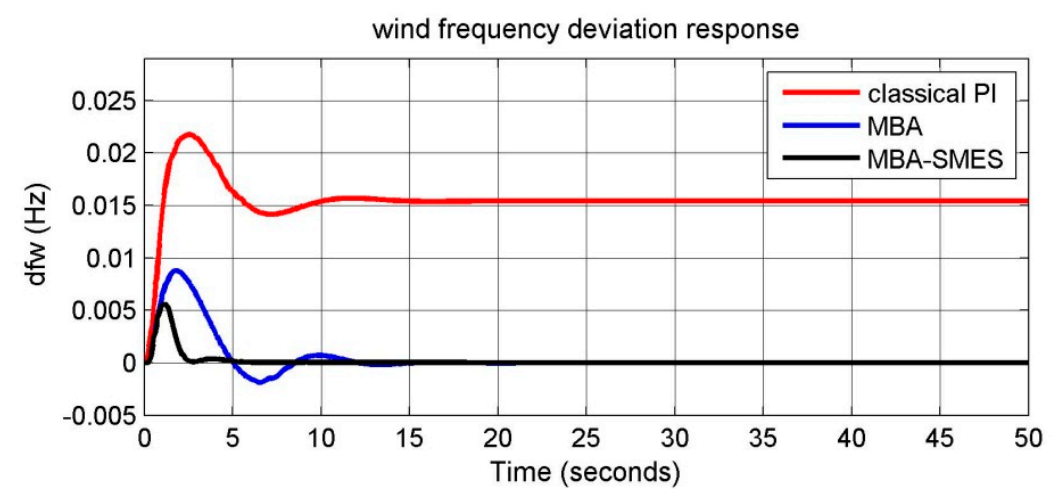

(a)

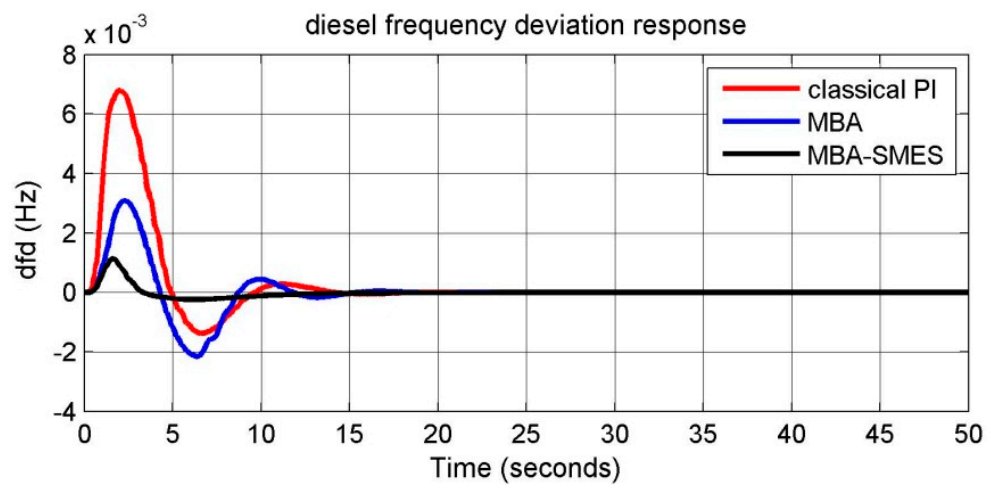

(b)

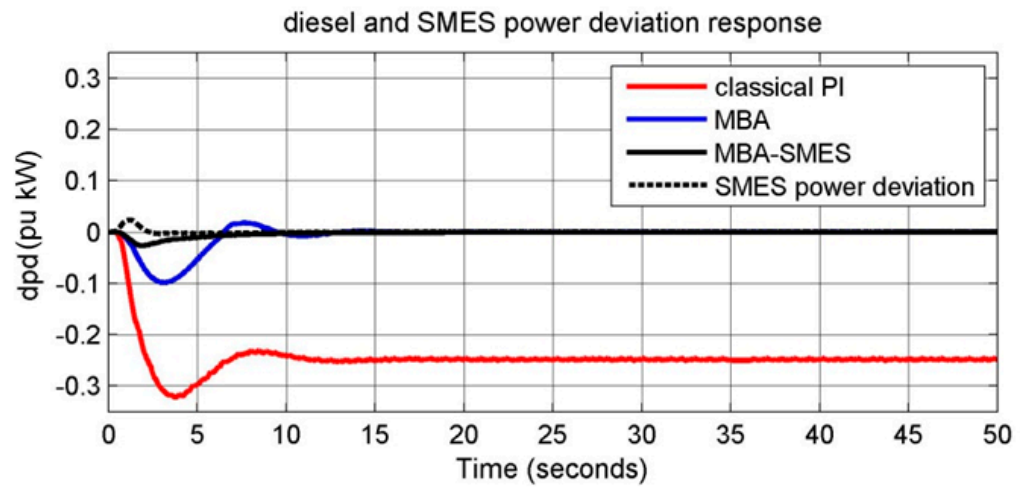

(c)

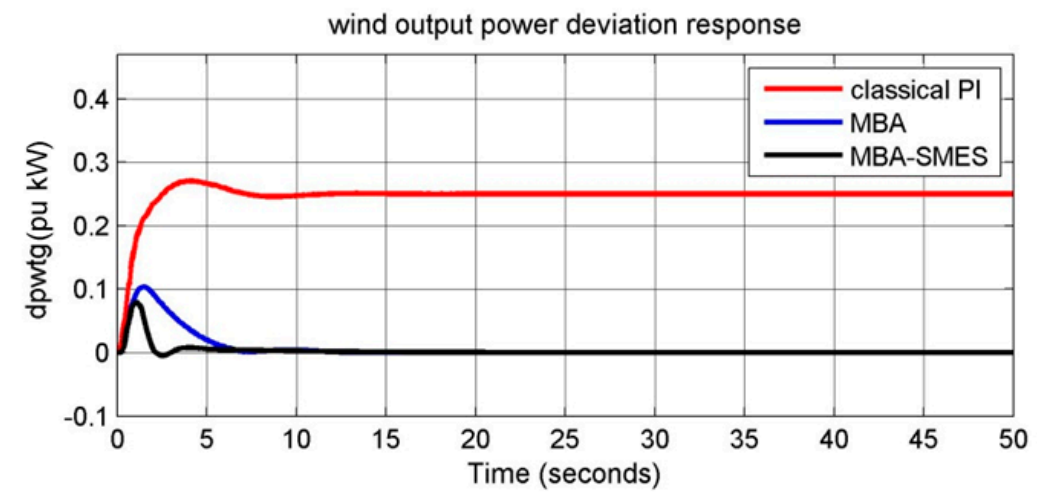

(d)

Figure 5. The system transient response curves for deviation in (a) wind frequency, (b) diesel frequency, (c) diesel output power, and (d) wind output power for $25 \%$ change in wind input power. 
Table 1. Wind frequency deviation performance parameters. ess: steady-state error; M.O: maximum overshoot; R.T: rise time; S.T: settling time, T.O.S: time of over shoot, U.S: under shoot.

\begin{tabular}{ccccc}
\hline & Phase of Comparison & Classical System & MBA System & $\begin{array}{c}\text { MBA-SMES } \\
\text { System }\end{array}$ \\
\cline { 2 - 5 } Wind Frequency & M.O (Hz) & 0.02174 & 0.00877 & 0.00559 \\
Performance & T.O.S (s) & 2.60942 & 2.10438 & 1.34680 \\
Parameters Under & U.S (Hz) & $1.42 \times 10^{-2}$ & $-1.87 \times 10^{-3}$ & $3.44 \times 10^{-7}$ \\
$\Delta \boldsymbol{P}_{\boldsymbol{w}}=\mathbf{0 . 2 5} \mathbf{p u ~ k W}$ & R.T (s) & 0.69267 & 0.02932 & 0.00551 \\
& S.T (s) & 13.923 & 13.657 & 6.217 \\
& ess (Hz) & $1.54 \times 10^{-2}$ & $2.37 \times 10^{-5}$ & $4.52 \times 10^{-7}$ \\
\hline
\end{tabular}

Table 2. Diesel frequency deviation performance parameters.

\begin{tabular}{ccccc}
\hline & Phase of Comparison & Classical System & MBA System & $\begin{array}{c}\text { MBA-SMES } \\
\text { System }\end{array}$ \\
\cline { 2 - 5 } Diesel Frequency & M.O (Hz) & 0.00678 & 0.00309 & 0.00113 \\
Performance & T.O.S (s) & 1.92034 & 2.27596 & 1.56472 \\
Parameters Under & U.S (Hz) & -0.00137 & -0.00216 & -0.00024 \\
$\Delta \boldsymbol{P}_{\boldsymbol{w}}=\mathbf{0 . 2 5} \mathbf{p u ~ k W}$ & R.T (s) & $4.28 \times 10^{-4}$ & $7.98 \times 10^{-5}$ & $4.23 \times 10^{-6}$ \\
& S.T (s) & 16.070 & 14.705 & 12.915 \\
& ess (Hz) & $-1.25 \times 10^{-6}$ & $-3.31 \times 10^{-8}$ & $-1.51 \times 10^{-8}$ \\
\hline
\end{tabular}

Table 3. Diesel power deviation performance parameters.

\begin{tabular}{ccccc}
\hline & Phase of Comparison & Classical System & MBA System & $\begin{array}{c}\text { MBA-SMES } \\
\text { System }\end{array}$ \\
\cline { 2 - 5 } Diesel Power & M.O (Hz) & 0.32209 & 0.09848 & 0.02663 \\
Performance & T.O.S (s) & 3.76956 & 3.12945 & 1.84922 \\
Parameters Under & U.S (Hz) & -0.32209 & -0.02663 & -0.00781 \\
$\Delta \boldsymbol{P}_{\boldsymbol{w}}=\mathbf{0 . 2 5} \mathbf{~ p u ~ k W ~}$ & R.T (s) & 1.15669 & 0.04055 & 0.00036 \\
& S.T (s) & 19.965 & 14.445 & 10.914 \\
& ess (Hz) & $-2.45 \times 10^{-1}$ & $1.97 \times 10^{-5}$ & $-4.41 \times 10^{-6}$ \\
\hline
\end{tabular}

Table 4. Wind output power deviation performance parameters.

\begin{tabular}{ccccc}
\hline & Phase of Comparison & Classical System & MBA System & $\begin{array}{c}\text { MBA-SMES } \\
\text { System }\end{array}$ \\
\cline { 2 - 5 } Wind Power & M.O (Hz) & 0.27048 & 0.10383 & 0.07923 \\
Parameters Under & T.O.S (s) & 3.98293 & 1.49359 & 1.06685 \\
$\Delta \boldsymbol{P}_{w}=\mathbf{0 . 2 5} \mathbf{~ p u ~ k W ~}$ & U.S (Hz) & $2.27 \times 10^{-1}$ & $-4.41 \times 10^{-3}$ & $-5.51 \times 10^{-5}$ \\
& R.T (s) & 1.51862 & 0.00113 & 0.00088 \\
& S.T (s) & 12.842 & 11.491 & 6.412 \\
& ess (Hz) & $2.50 \times 10^{-1}$ & $1.75 \times 10^{-6}$ & $1.37 \times 10^{-6}$ \\
\hline
\end{tabular}

\subsection{Case 2}

The proposed system was tested to confirm its effectiveness. The operating conditions were represented as $5 \%$ change in load power with $25 \%$ change in wind input power. Results are presented in Figure 6 showing the system dynamic response of the three control schemes including the wind frequency, diesel frequency, diesel output power, and wind output power. From Figure 6a and Table 5, the wind frequency deviation response was clearly enhanced by decreasing M.O to $0.00525 \mathrm{~Hz}$ (0.25 times of classical and 0.67 of MBA systems), R.T to $0.00032 \mathrm{~s}\left(4.21 \times 10^{-4}\right.$ of classical and 0.6545 MBA systems), and S.T to 7.91445 s (0.8413 of classical and 0.7022 MBA systems).

More illustrative results can be obtained from Figure $5 \mathrm{~b}$ to Figure $6 \mathrm{~d}$ and in the tables below (Tables 6-8). As in Figure 6c, the MBA-SMES system set the output power deviation to 0.05 pu kW with 
M.O to $3.63247 \mathrm{~Hz}$ ( 0.67 of MBA system). Moreover, Figure $6 \mathrm{~d}$ illustrates the wind power deviations of all systems. The difference of turbine output power reference was set to zero (pu $\mathrm{kW})$. The proposed system based on MBA-SMES damped the output power oscillations and the blade pitch controller set the output power deviation to zero (pu kW) by setting the M.O to $0.083005 \mathrm{~Hz}$ ( 0.1 of MBA systems) and the S.T to $6.455 \mathrm{~s}$ ( 0.576 of MBA systems).

This improvement was because the SMES system discharged its power in a very short time, as can be seen in Figure 6c. This action aided the main system in withstanding the disturbances in load and wind power. In addition, the steady-state error reached zero.

Table 5. Wind frequency deviation performance parameters.

\begin{tabular}{ccccc}
\hline & Phase of Comparison & Classical System & MBA System & $\begin{array}{c}\text { MBA-SMES } \\
\text { System }\end{array}$ \\
\cline { 2 - 5 } Wind Frequency & M.O (Hz) & 0.02050 & 0.00775 & 0.00525 \\
Performance & T.O.S (s) & 2.5641 & 1.6382 & 1.1396 \\
Parameters Under & U.S (Hz) & 0.01422 & -0.00163 & -0.00119 \\
$\Delta \boldsymbol{P}_{\boldsymbol{w}}=\mathbf{0 . 2 5} \mathbf{~ p u ~ k W ~}$ & R.T (s) & 0.75442 & 0.00048 & 0.00032 \\
$\boldsymbol{\Delta} \boldsymbol{P}_{\text {load }}=\mathbf{0 . 0 5} \mathbf{~ p u ~ k W ~}$ & S.T (s) & 9.407 & 11.271 & 7.914 \\
& ess (Hz) & $1.54 \times 10^{-2}$ & $4.63 \times 10^{-8}$ & $1.51 \times 10^{-8}$ \\
\hline
\end{tabular}

Table 6. Diesel frequency deviation performance parameters.

\begin{tabular}{ccccc}
\hline & Phase of Comparison & Classical System & MBA System & $\begin{array}{c}\text { MBA-SMES } \\
\text { System }\end{array}$ \\
\cline { 2 - 5 } Diesel Frequency & & 5.13675 & 4.91168 & 3.63247 \\
Performance & M.O (Hz) & -0.00110 & -0.00208 & -0.00115 \\
Parameters Under & T.O.S (s) & 0.02637 & 0.03174 & 0.00011 \\
$\Delta \boldsymbol{P}_{\boldsymbol{w}}=\mathbf{0 . 2 5} \mathbf{p u ~ k W}$ & U.S (Hz) & 13.004 & 14.561 & 12.436 \\
$\Delta \boldsymbol{P}_{\text {load }}=\mathbf{0 . 0 5} \mathbf{~ p u ~ k W ~}$ & R.T (s) & 2.1367 & 5.91168 & 3.63247 \\
& S.T (s) & $-1.09 \times 10^{-6}$ & $-2.49 \times 10^{-7}$ & $7.54 \times 10^{-8}$ \\
\hline
\end{tabular}

Table 7. Diesel power deviation performance parameters.

\begin{tabular}{ccccc}
\hline & Phase of Comparison & Classical System & MBA System & $\begin{array}{c}\text { MBA-SMES } \\
\text { System }\end{array}$ \\
\cline { 2 - 5 } Diesel Power & M.O (Hz) & 0.2576375 & 0.0652 & 0.05002 \\
Performance & T.O.S (s) & 3.7749287 & 6.98005 & 4.8575 \\
Parameters Under & U.S (Hz) & -0.2576375 & 0.04244 & 0.04516 \\
$\Delta \boldsymbol{P}_{\boldsymbol{w}}=\mathbf{0 . 2 5} \mathbf{~ p u ~ k W ~}$ & R.T (s) & 1.2329223 & 1.31724 & 3.61641 \\
$\boldsymbol{\Delta} \boldsymbol{P}_{\text {load }}=\mathbf{0 . 0 5} \mathbf{~ p u ~ k W ~}$ & S.T (s) & 10.894785 & 12.3499 & 9.3131 \\
& ess (Hz) & -0.199296 & 0.050165 & 0.050001 \\
\hline
\end{tabular}

Table 8. Wind output power deviation performance parameters.

\begin{tabular}{ccccc}
\hline & Phase of Comparison & Classical System & MBA System & $\begin{array}{c}\text { MBA-SMES } \\
\text { System }\end{array}$ \\
\cline { 2 - 5 } Wind Power & M.O (Hz) & 0.26646 & 0.10946 & 0.08300 \\
Performance Under & T.O.S (s) & 4.20227 & 1.42450 & 1.13960 \\
$\boldsymbol{\Delta} \boldsymbol{P}_{\boldsymbol{w}}=\mathbf{0 . 2 5} \mathbf{~ p u ~ k W ~}$ & U.S (Hz) & $2.28 \times 10^{-1}$ & $-7.84 \times 10^{-6}$ & $-6.39 \times 10^{-3}$ \\
$\boldsymbol{\Delta} \boldsymbol{P}_{\text {load }}=\mathbf{0 . 0 5} \mathbf{~ p u ~ k W ~}$ & R.T (s) & $1.51 \times 10^{1}$ & $2.86 \times 10^{-3}$ & $2.09 \times 10^{-5}$ \\
& S.T (s) & 12.828 & 11.205 & 6.456 \\
& ess (Hz) & $2.50 \times 10^{-1}$ & $4.79 \times 10^{-6}$ & $-9.76 \times 10^{-7}$ \\
\hline
\end{tabular}




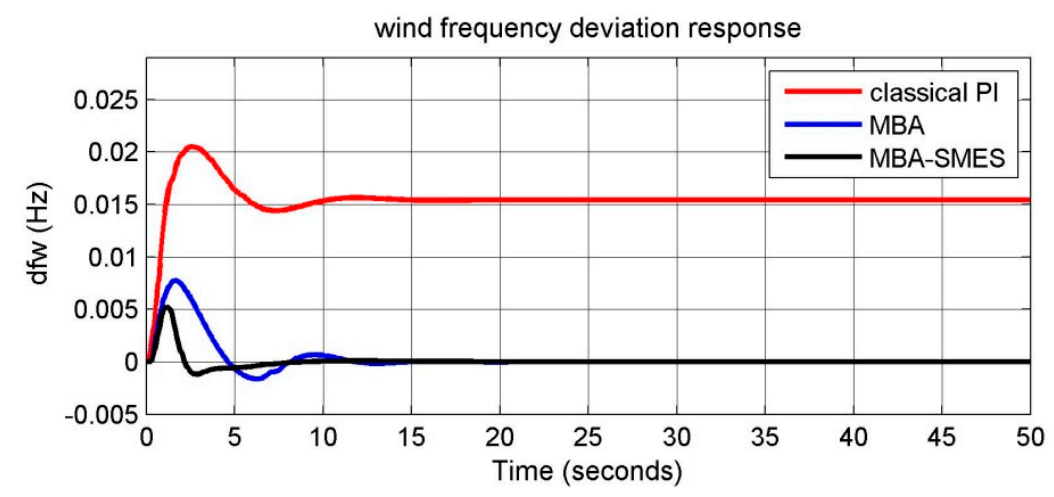

(a)

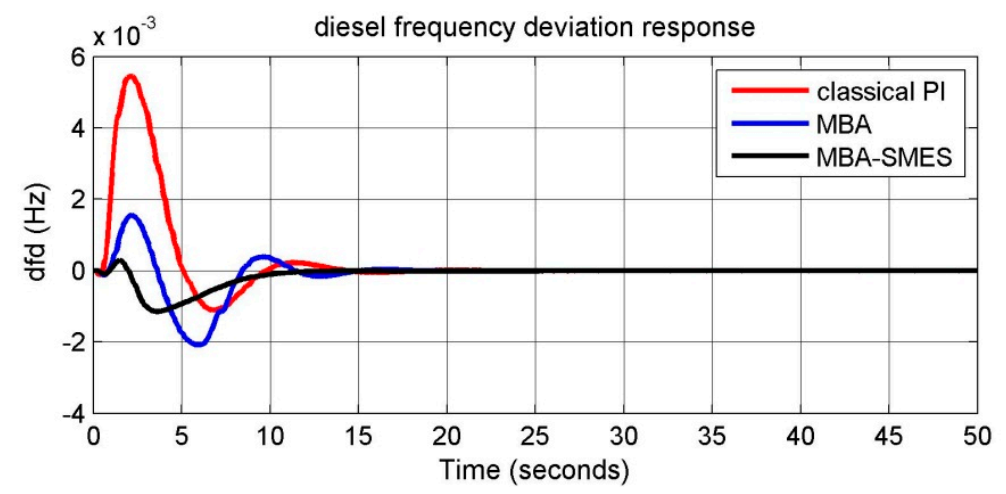

(b)

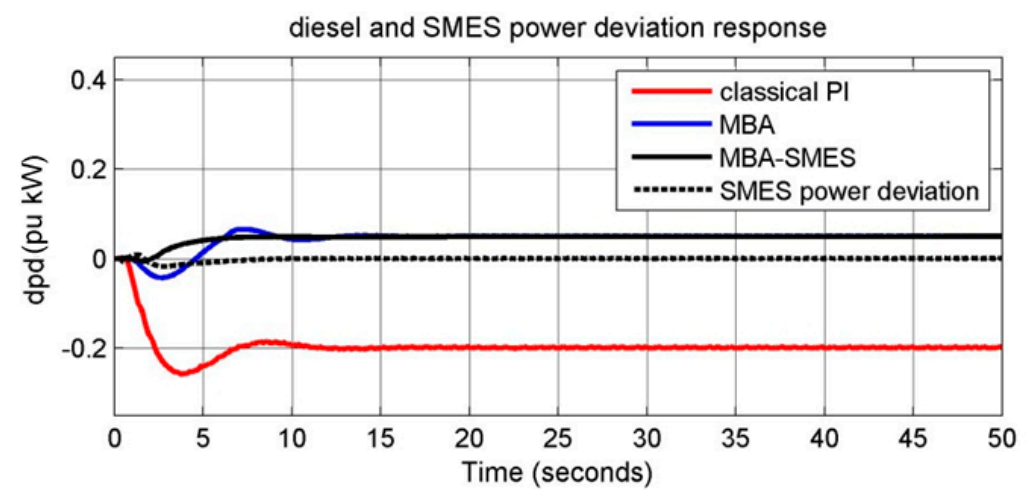

(c)

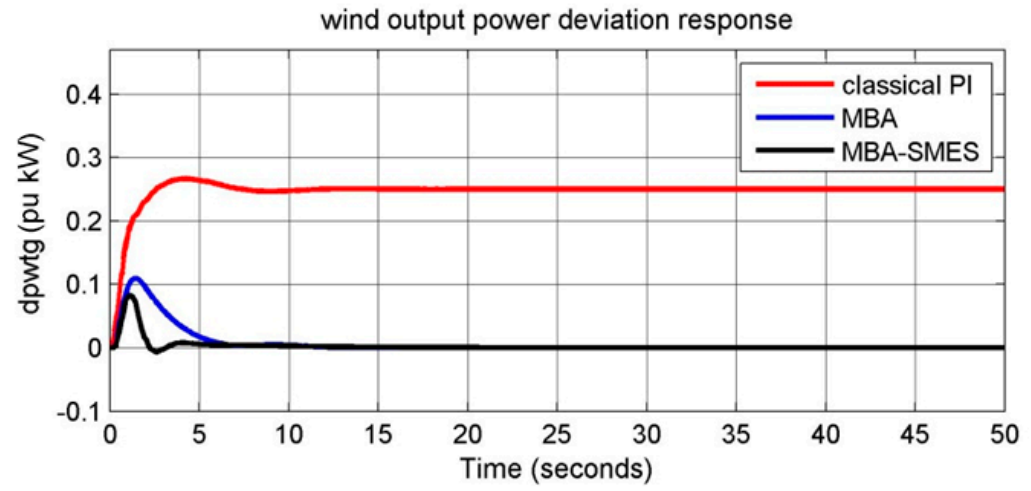

(d)

Figure 6. The system transient response curves for deviation in (a) wind frequency, (b) diesel frequency, (c) diesel output power, and (d) wind output power for 5\% step load change and $25 \%$ change in input wind power. 


\subsection{Case 3}

The studied systems were subjected to wind gust (random wind input power) as seen in Figure 7. As mentioned previously, using an anemometer is necessary to measure the wind speed and its direction. In this study, the input change in wind speed measured by the anemometer was simulated by variation in the wind input power, as any variation in the wind speed will be reflected into a variation in the turbine input power $\left(\Delta P_{w}\right)$. The simulation results in Figure 8 show that the MBA-SMES system was better than that of the classical and MBA systems. As illustrated in Figure $8 \mathrm{a}$, the wind frequency deviation of the MBA-SMES system oscillated between $-0.4 \times 10^{-3}$ and $0.4 \times 10^{-3} \mathrm{~Hz}$ around zero, while the MBA system oscillates between $-1.2 \times 10^{-3}$ and $1.1 \times 10^{-3} \mathrm{~Hz}$ around zero and the classical system oscillated between $-2.5 \times 10^{-3}$ and $4.5 \times 10^{-3} \mathrm{~Hz}$ around $2.5 \times 10^{-3} \mathrm{~Hz}$. The MBA-SMES system gave the better response for the frequency and power deviation responses compared to other systems. This also can be seen in the remaining figures (Figure $8 b-d$ ).

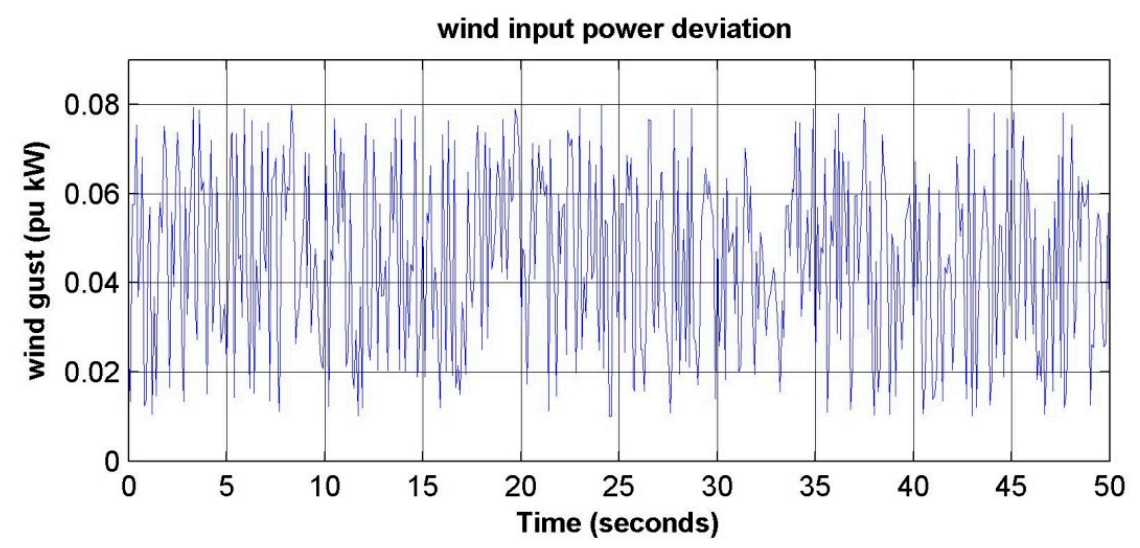

Figure 7. Random wind input power.

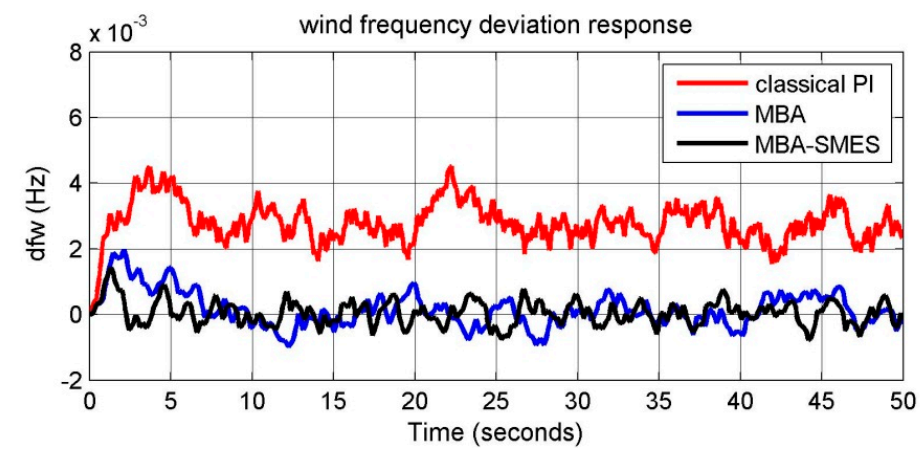

(a)

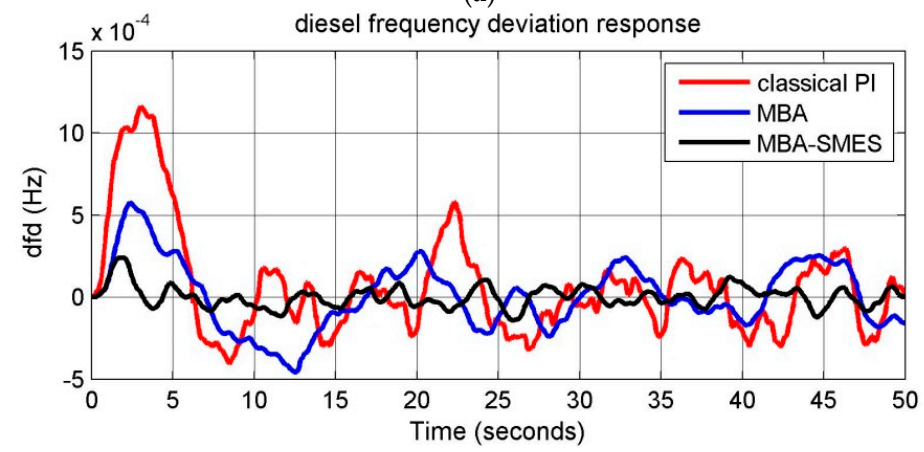

(b)

Figure 8. Cont. 


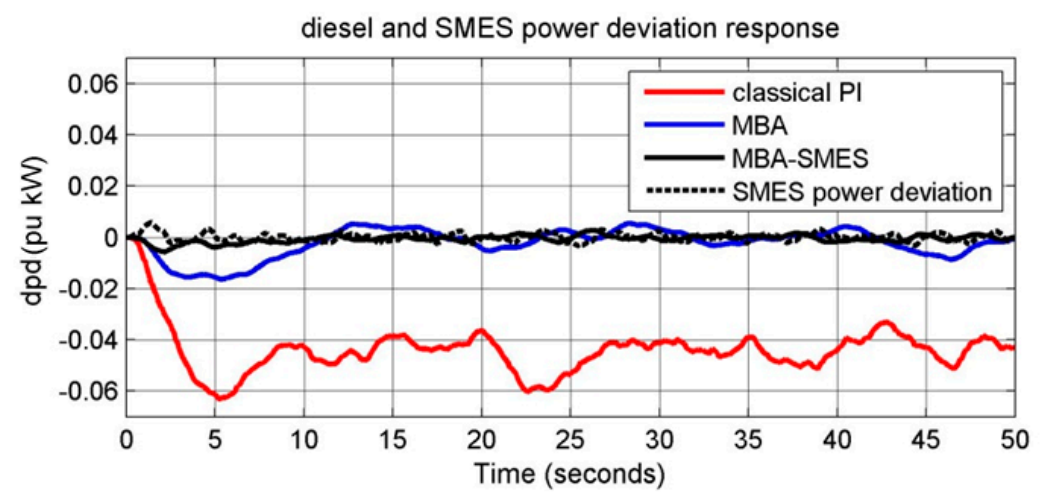

(c)

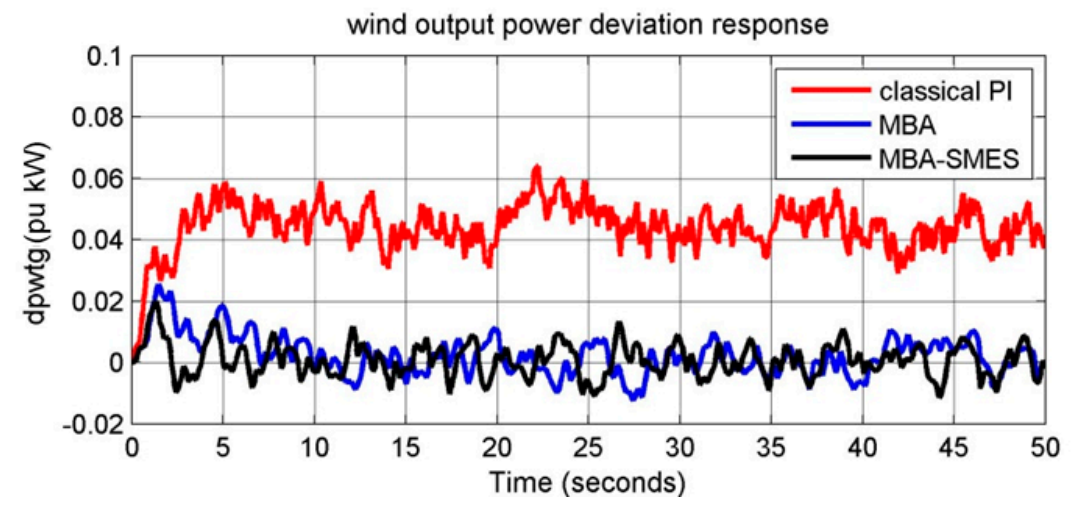

(d)

Figure 8. The system transient response curves for deviation in (a) wind frequency, (b) diesel frequency, (c) diesel output power, and (d) wind output power for random input wind power.

\subsection{Case 4}

The systems were tested under harsh conditions to confirm their effectiveness. The operating conditions were represented as 5\% change in load power with $25 \%$ change in input wind power and $25 \%$ decrease in $K_{f c} . K_{f_{c}}$ was selected because it is the dominant parameter in the hybrid system [20]. Results are presented in Figure $9 \mathrm{a}-\mathrm{d}$ and show that the system dynamic response of the proposed MBA-based control scheme could withstand these severe operating conditions. It can be verified from Table 9 that the MBA-SMES system decreased the maximum overshoot to $0.0045 \mathrm{~Hz}(0.2549$ of classical and 0.689 of MBA based systems) and the settling time to $8.54552 \mathrm{~s}$. The simulation results prove the robustness and effectiveness of the proposed MBA-SMES-based controller over MBA and PI classical systems.

Table 9. Wind frequency deviation performance parameters.

\begin{tabular}{ccccc}
\hline & Phase of Comparison & Classical System & MBA System & $\begin{array}{c}\text { MBA-SMES } \\
\text { System }\end{array}$ \\
\cline { 2 - 5 } Performance & M.O (Hz) & 0.01768 & 0.00653 & 0.00451 \\
parameters Under & T.O.S (s) & 2.38784 & 1.59189 & 1.08538 \\
$\Delta \boldsymbol{P}_{w}=\mathbf{0 . 2 5} \mathbf{~ p u ~ k W ~}$ & U.S (Hz) & 0.01122 & -0.00165 & -0.00094 \\
$\boldsymbol{\Delta} \boldsymbol{P}_{\text {load }}=\mathbf{0 . 0 5} \mathbf{~ p u}$ & R.T (s) & $6.79 \times 10^{-1}$ & $9.95 \times 10^{-4}$ & $2.53 \times 10^{-5}$ \\
$\mathbf{k W ~} K_{f c}=\mathbf{1 . 2 5} K_{f c}$ & S.T (s) & 9.4343 & 12.6615 & 8.5455 \\
& ess (Hz) & $1.23 \times 10^{-2}$ & $4.68 \times 10^{-8}$ & $-1.27 \times 10^{-7}$ \\
\hline
\end{tabular}




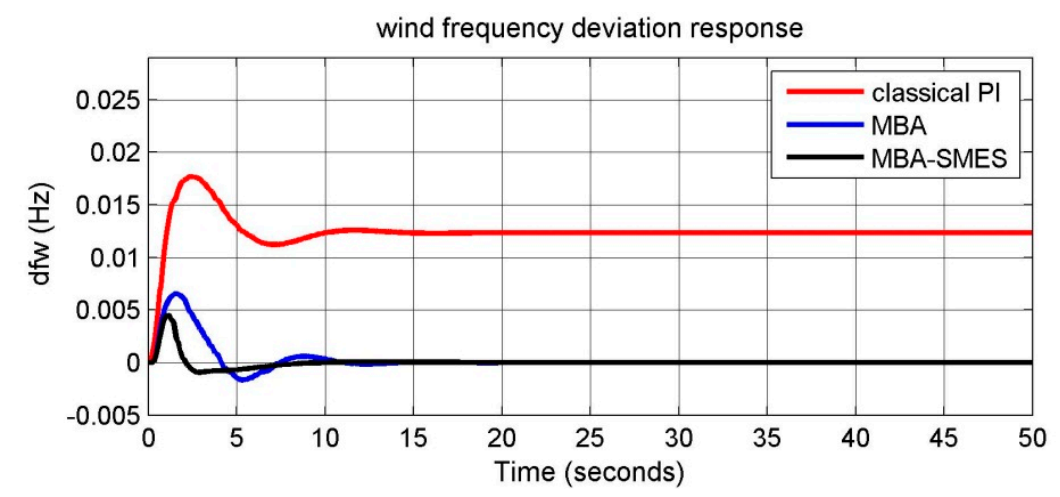

(a)

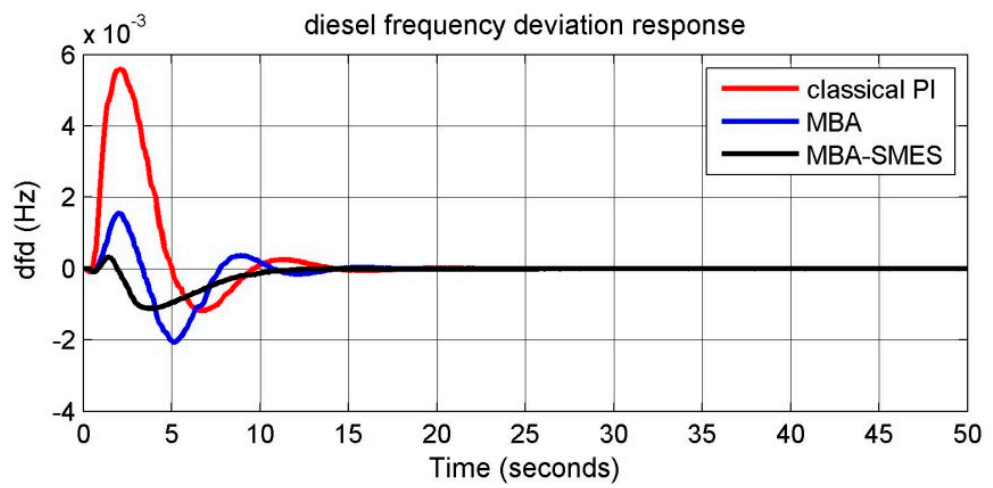

(b)

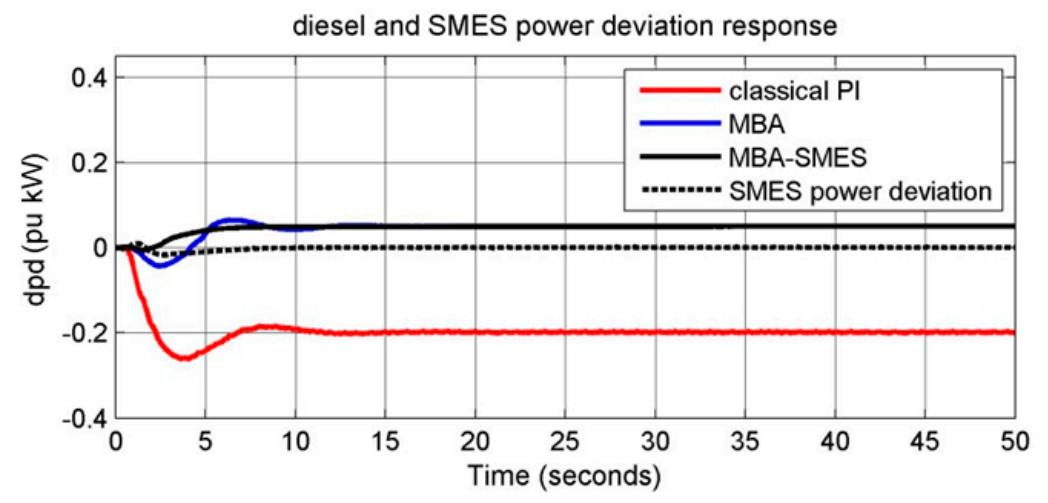

(c)

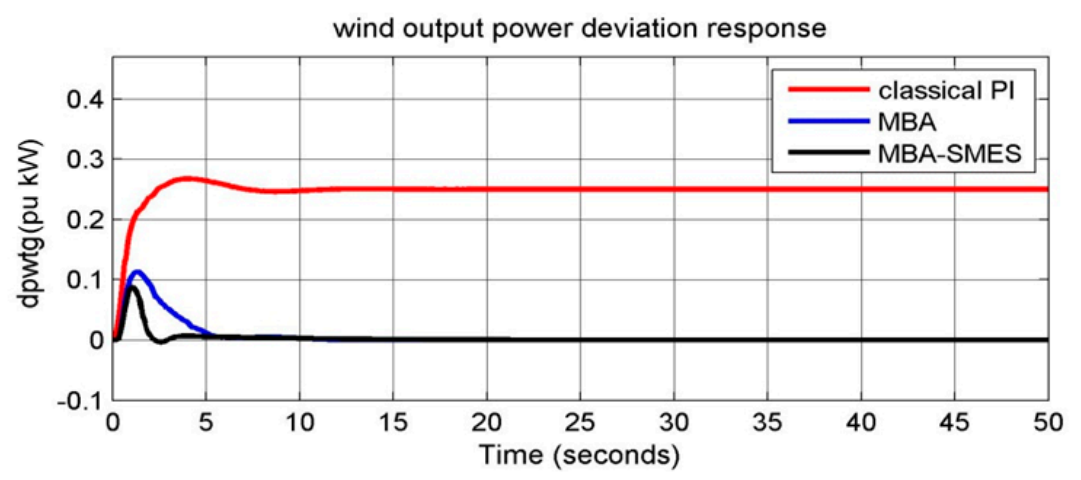

(d)

Figure 9. The system transient response curves deviation in (a) wind frequency, (b) diesel frequency, (c) diesel output power, and (d) wind output power for 5\% step load change with $25 \%$ change in input wind power and $25 \% K_{f c}$. 


\subsection{Case 5}

In this case, systems were tested under parameter variation conditions to confirm their effectiveness. The fluid coupling coefficient was selected as mentioned above (the control system response is sensitive to this parameter). The operating conditions were represented as $5 \%$ change in load power, $25 \%$ change in wind input power, and a variation in $K_{f c}$ from $-30 \%$ to $30 \%$. The performance index used was the IAE. Results are presented in Figures 10 and 11 and show the system dynamic response of the systems. As the fluid coupling decreased, the IAE values of the classical PI system increased sharply. However, the values of the proposed MBA-SMES scheme were much lower, and almost constant.

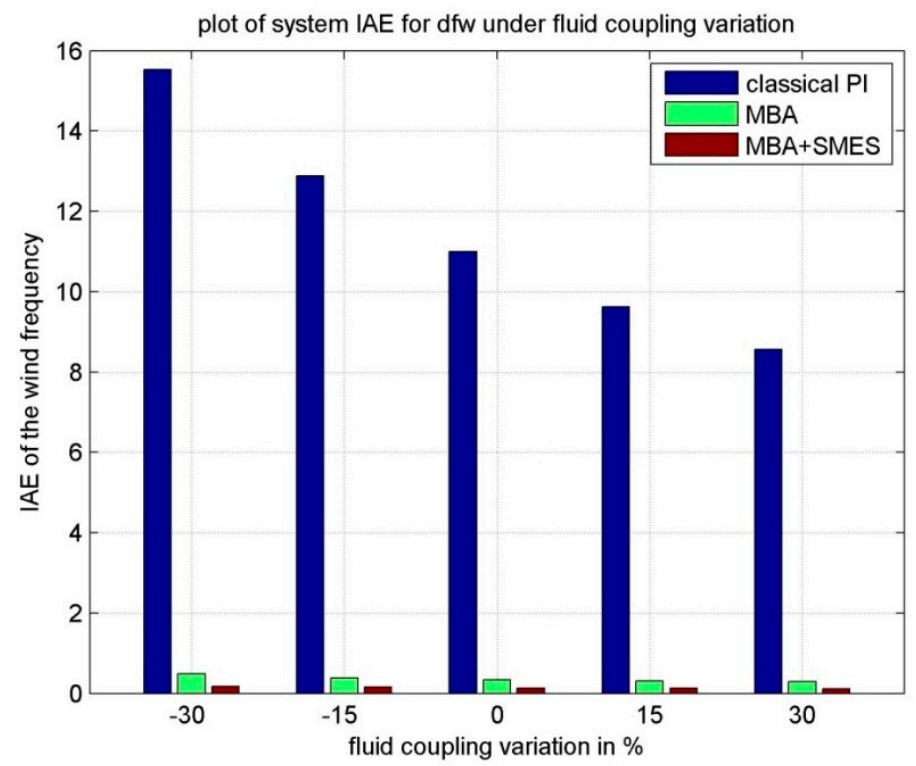

Figure 10. Integral of absolute error (IAE) for wind frequency deviation under the change in $K_{f c}$.

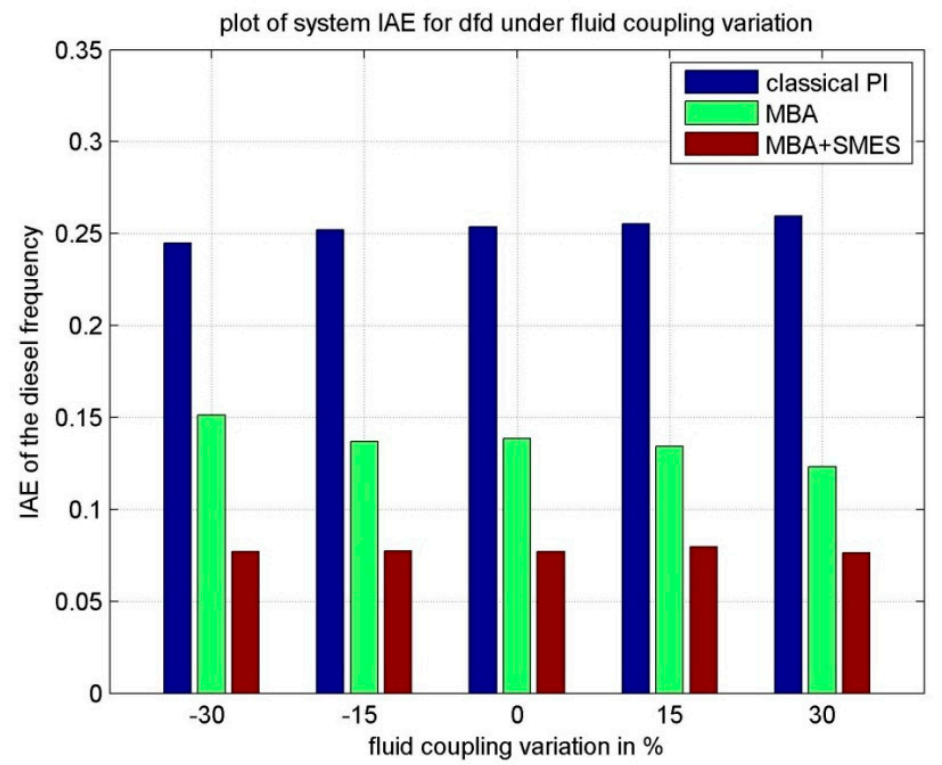

Figure 11. IAE for diesel frequency deviation under change in $K_{f c}$.

Table 10 shows the MBA-SMES system's response under fluid coupling variation. At the change in $K_{f c}$ equal to $-30 \%$ and $30 \%$, the steady state error change was $1.25 \%$. For rise time, the change from base case (no fluid coupling change) did not exceed $0.5 \%$. The settling time change did not exceed $5 \%$. From the discussion it can be observed that all performance parameters varied within acceptable limits 
and were approximately equal to the obtained values with the nominal system. So, the MBA-SMES based system was robust for fluid coupling variation and effective compared to other systems.

Table 10. System frequency performance parameters under fluid coupling variation.

\begin{tabular}{|c|c|c|c|c|c|c|c|c|c|}
\hline & & \multicolumn{8}{|c|}{ Wind and Diesel Frequencies } \\
\hline & & \multicolumn{4}{|c|}{$\Delta f_{w}$} & \multicolumn{4}{|c|}{$\Delta f_{d}$} \\
\hline & & M.O (Hz) & R.T (s) & S.T (s) & ess $(\mathrm{Hz})$ & M.O (Hz) & R.T (s) & S.T (s) & ess $(\mathrm{Hz})$ \\
\hline \multirow{5}{*}{$K_{f c}$} & -30 & 0.0069 & $2.59 \times 10^{-5}$ & 7.406 & $-2.10 \times 10^{-7}$ & 0.0012 & 0.00096 & 12.239 & $4.95 \times 10^{-7}$ \\
\hline & -15 & 0.0059 & $2.81 \times 10^{-6}$ & 7.419 & $-1.87 \times 10^{-8}$ & 0.0012 & 0.00016 & 12.335 & $2.24 \times 10^{-7}$ \\
\hline & 0 & 0.0053 & $3.18 \times 10^{-4}$ & 7.914 & $1.52 \times 10^{-8}$ & 0.0012 & 0.00011 & 12.436 & $7.55 \times 10^{-8}$ \\
\hline & 15 & 0.0048 & $1.79 \times 10^{-6}$ & 8.406 & $-1.16 \times 10^{-8}$ & 0.0012 & 0.00033 & 12.471 & $2.39 \times 10^{-7}$ \\
\hline & 30 & 0.0044 & $2.76 \times 10^{-5}$ & 8.473 & $-1.33 \times 10^{-7}$ & 0.0012 & 0.00055 & 12.283 & $5.16 \times 10^{-7}$ \\
\hline
\end{tabular}

\section{Conclusions}

A robust MBA-based control scheme of the isolated hybrid wind-diesel system was designed in this paper to tune the gains of two controllers. The first were the PID gains of the blade pitch controller and the second were those of the SMES controller. The MBA-SMES system was compared with the classical PI- and MBA-based controllers. Five case studies were considered in the simulation under load and input wind power disturbances and harsh conditions with parameter variation for the fluid coupling of the wind and diesel generators. The simulation results confirmed the effectiveness and robustness of the proposed MBA-SMES system compared with other systems. The main improvements can be summarized in the following points.

- The proposed MBA-SMES system was able to damp the output deviation in frequencies and power of the system, reducing overshoot and settling time. For wind frequency, the MBA-SMES maximum overshoot was reduced to $0.00559 \mathrm{~Hz}$ ( 0.25 of classical system), it reached its peak value in $1.346 \mathrm{~s}$ (approximately 0.5 of classical), the rise time was about $0.00551 \mathrm{~s}(0.008$ of classical system), meaning that the reduction percent reached $75 \%$ of the classical system. Its settling time was $6.2166 \mathrm{~s}$ ( 0.4465 of classical system).

- The main improvements were due to the existence of SMES system, which aided the main system in responding to the disturbances. For wind frequency, MBA-SMES reduced overshoot to $0.00637 \mathrm{~Hz}$ ( 0.63 of MBA system) in $1.346 \mathrm{~s}$ ( 0.64 of MBA system). This means that the reduction percent reached $36 \%$ that of the MBA system, the rise time was $0.00551 \mathrm{~s}(0.19$ of MBA system), and the settling time was $6.2166 \mathrm{~s}$ (0.18 of MBA system).

- The MBA-SMES based system was robust to fluid coupling variation and was effective compared to other systems. At the change in $K_{f c}$ ranging from $-30 \%$ to $30 \%$, the steady state error change was $1.25 \%$. For rise time, the change from base case did not exceed $0.5 \%$. The settling time change did not exceed $5 \%$. Values of the performance parameters varied within acceptable limits, and were near the obtained values with the nominal system parameters.

- The MBA optimization algorithm was a very robust technique; it had better selectivity than the gains of PID blade pitch and SMES controllers. Also, this algorithm is simple and converged quickly during the optimization process.

It is recommended to use MBA after modification for solving multi-objective optimization systems to optimize the hybrid system under multi-objective functions such as the mechanical stress on the wind turbine blades. In addition, wind-diesel control systems can be combined with photovoltaic systems, battery storage, fuel cells, etc., enlarging the scale of hybrid systems from small-scale (micro-grid of $350 \mathrm{~kW}$ capacities) to medium- and large-scale power systems. 
Author Contributions: A.H.A., S.I.S., H.M.B.M., A.I., and R.A. developed the idea, carried out the study, prepared the models, analyzed the corresponding results, and wrote the paper. A.M.E.-R. and M.A.T. contributed by drafting and critical revisions. All authors together organized and refined the manuscript in the present form.

Funding: This research received no external funding.

Conflicts of Interest: All of the authors declare no conflict of interest.

\section{List of Abbreviations}

$\begin{array}{ll}\text { IAE } & \text { Integral of absolute error } \\ \text { MBA } & \text { Mine blast algorithm } \\ \text { PSO } & \text { Particle swarm optimization algorithm } \\ \text { BFO } & \text { Bacterial forging optimization } \\ \text { BCO } & \text { Bee colony optimization algorithm } \\ \text { MHSA } & \text { Modified harmony search algorithm } \\ \text { GBMO } & \text { Gases Brownian motion optimization } \\ \text { DMP } & \text { Distributed model predictive } \\ \text { MBIA } & \text { Modified bat-inspired algorithm } \\ \text { PID } & \text { Proportional-integral-differential } \\ \text { PI } & \text { Proportional-integral } \\ \text { SMES } & \text { Superconducting magnetic energy storage }\end{array}$

\section{Appendix A}

Table A1. Wind, diesel, and SMES data.

\begin{tabular}{ll} 
Wind generator rating & $150 \mathrm{~kW}$ \\
Diesel generators rating & $200 \mathrm{~kW}$ \\
Load demand power & $350 \mathrm{~kW}$ \\
Inertia constant of wind system, $H_{w}$ & $3.5 \mathrm{~s}$ \\
Inertia constant of diesel system, $H_{d}$ & $8.5 \mathrm{~s}$ \\
Fluid coupling of the hybrid wind and diesel system, $K_{f c}$ & $16.2 \mathrm{pu} \mathrm{kW} / \mathrm{Hz}$ \\
Governor gain, $K_{d}$ & $16.5 \mathrm{pu} \mathrm{kW} / \mathrm{Hz}$ \\
Governor time constant $T_{1}$ & $0.025 \mathrm{~s}$ \\
The hydraulic pitch actuator gain $K_{p 2}$ & 1.25 \\
The time constant of hydraulic pitch actuator $T_{p 1}$ & $0.6 \mathrm{~s}$ \\
The time constant of pitch actuator $T_{p 2}$ & $0.041 \mathrm{~s}$ \\
Gain of data fit pitch response, $K_{p 3}$ & 1.4 \\
Blade pitch characteristic gain, $K_{p c}$ & $0.08 \mathrm{pu} \mathrm{kW} / \mathrm{deg}$ \\
SMES time constant $T_{s m}$ & $0.03 \mathrm{~s}$ \\
\hline
\end{tabular}

\section{References}

1. Hunter, R.; Elliot, G. Wind-Diesel Systems. A Guide to Technology and Its Implementation; University Press: Cambridge, UK, 1994.

2. Senjyu, T.; Omine, E.; Hayashi, D.; Sekine, H.; Funabashi, T. Application of decentralized control for remote power system stabilization by installing renewable energy power plant. IEEJ Trans. Electr. Electron. Eng. 2008, 3, 473-481. [CrossRef]

3. Khelif, A.; Talha, A.; Belhamel, M.; Arab, A.H. Feasibility study of hybrid Diesel-PV power plants in the southern of Algeria: Case study on AFRA power plant. Int. J. Electr. Power Energy Syst. 2013, 43, 553-564. [CrossRef]

4. Kassem, A.M.; Yousef, A.M. Robust control of an isolated hybrid wind-diesel power system using Linear Quadratic Gaussian approach. Int. J. Electr. Power Energy Syst. 2011, 33, 1092-1100. [CrossRef]

5. Hu, Y.; Morales, J.M.; Pineda, S.; Sánchez, M.J.; Solana, P. Dynamic multi-stage dispatch of isolated wind diesel power systems. Energy Convers. Manag. 2015, 103, 605-615. [CrossRef]

6. Bernal-Agustín, J.L.; Dufo-Lopez, R. Simulation and optimization of stand-alone hybrid renewable energy systems. Renew. Sustain. Energy Rev. 2009, 13, 2111-2118. [CrossRef] 
7. Lipman, N.H. Overview of wind/diesel systems. Renew. Energy 1994, 5, 595-617. [CrossRef]

8. Das, D.; Roy, A.; Sinha, N. GA Based Frequency Controller for Solar Thermal-Diesel-Wind Hybrid Energy Generation/Energy Storage System. Int. J. Electr. Power Energy Syst. 2012, 43, 262-279. [CrossRef]

9. Sebastian, R.; Alzola, R. Simulation of an Isolated Wind Diesel System with Battery Energy Storage. Int. J. Electr. Power Syst. Res. 2011, 81, 677-686. [CrossRef]

10. Tripathy, S.C.; Kalantar, M.; Balasubramanian, R. Dynamics and stability of a hybrid wind-diesel power system. Energy Convers. Manag. 1992, 33, 1063-1072. [CrossRef]

11. Tripathy, S.C.; Kalantar, M.; Balasubramanian, R. Stability simulation and parameter optimization of a hybrid wind-diesel power generation system. Int. J. Energy Res. 1992, 16, 31-42. [CrossRef]

12. Bhatti, T.S.; Bansal, N.K. Load frequency control of isolated wind diesel hybrid power systems. Energy Convers. Manag. 1997, 38, 829-837. [CrossRef]

13. Bhatti, T.S.; Al-Ademi, A.A.F.; Bansal, N.K. Dynamics and control of isolated wind-diesel power systems. Int. J. Energy Res. 1995, 19, 729-740. [CrossRef]

14. Supriyadi, C.; Nandar, A. Parameter Optimization of Pitch Controller for Robust Frequency Control in an Isolated Wind-diesel Hybrid Power System Using Genetic Algorithm. TELKOMNIKA 2008, 6, 145-154.

15. Lotfy, M.; Senjyu, T.; Farahat, M.; Abdel-Gawad, A.; Yona, A. A Frequency Control Approach for Hybrid Power System Using Multi-Objective Optimization. Energies 2017, 10, 80. [CrossRef]

16. Supriyadi, A.N.C.; Takano, H.; Murata, J.; Goda, T.; Hashiguchi, T. Adaptive frequency control for hybrid wind-diesel power system using system estimator. In Proceedings of the IEEE International Conference on Power System Technology (POWERCON), Auckland, New Zealand, 30 October-2 November 2012; pp. 1-6.

17. Supriyadi, A.; Nandar, A. Robust PI control of smart controllable load for frequency stabilization of microgrid power system. Renew. Energy 2013, 56, 16-23.

18. Tarkeshwar, M.; Mukherjee, V. A novel quasi-oppositional harmony search algorithm and fuzzy logic controller for frequency stabilization of an isolated hybrid power system. Int. J. Electr. Power Energy Syst. 2015, 66, 247-276. [CrossRef]

19. Lasheen, A.; Elshafei, A. Wind-turbine collective-pitch control via fuzzy predictive algorithm. Renew. Energy 2016, 87, 298-306. [CrossRef]

20. Viveiros, C.; Melício, R.; Igreja, J.; Mendes, V.M.F. Performance assessment of a wind energy conversion system using a hierarchical controller structure. Energy Convers. Manag. 2015, 93, 40-48. [CrossRef]

21. Dahbi, A.; Nait-Said, N.; Nait-Said, M.S. A novel combined MPPT pitch angle control for wide range variable speed wind turbine based on neural network. Int. J. Hydrogen Energy 2015, 41, 9427-9442. [CrossRef]

22. Kumari, N.; Jha, A.N. Frequency Response Enhancement of Hybrid Power System by Using PI Controller Tuned with PSO Technique. Int. J. Adv. Comput. Res. 2014, 4, 116-122.

23. Ali, R.; Mohamed, T.; Qudaih, Y.; Mitani, Y. A New Load Frequency Control Approach in an Isolated Small Power Systems Using Coefficient Diagram Method. Int. J. Electr. Power Energy Syst. 2014, 56, 110-116. [CrossRef]

24. Borhanazad, H.; Mekhilef, S.; Ganapathy, V.G.; Delshad, M.M.; Mirtaheri, A. Optimization of micro-grid system using MOPSO. Renew. Energy 2014, 71, 295-306. [CrossRef]

25. Behera, S.; Subudhi, B.; Pati, B.B. Design of PI controller in pitch control of wind turbine: A comparison of PSO and PS algorithm. Int. J. Renew. Energy Res. 2016, 6, 271-281.

26. Farag, K.; Abo-Elyousr, F.K.; Elnozahy, A.A. Bi-objective economic feasibility of hybrid micro-grid systems with multiple fuel options for islanded areas in Egypt. Renew. Energy 2018, 128, 37-56.

27. Chaiyatham, T.; Ngamroo, I.; Pothiya, S.; Vachirasricirikul, S. Design of Optimal Fuzzy Logic-PID Controller Using Bee Colony Optimization for Frequency Control in an Isolated Wind-Diesel System. In Proceedings of the Transmission and Distribution Conference and Exposition: Asia and Pacific, Seoul, Korea, 26-30 October 2009.

28. Mishra, S.; Mallesham, G.; Jha, A. Design of Controller and Communication for Frequency Regulation of a Smart Microgrid. IET Renew. Power Gener. 2012, 6, 6248-6258. [CrossRef]

29. Howlader, A.M.; Izumi, Y.; Uehara, A.; Urasaki, N.; Senjyu, T.; Saber, A. A robust H controller based frequency control approach using the wind battery coordination strategy in a small power system. Int. J. Electr. Power Energy Syst. 2014, 58, 190-198. [CrossRef]

30. Muhando, B.E.; Wies, R.W. Nonlinear H constrained feedback control for grid-interactive WECS under high stochasticity. IEEE Trans. Energy Convers. 2011, 26, 1000-1009. [CrossRef] 
31. Barisal, A.K.; Nayak, S.K. Load frequency control of wind diesel hybrid power system using DE algorithm. In Proceedings of the 10th International Conference on Intelligent Systems and Control (ISCO), Coimbatore, India, 7-8 January 2016; pp. 1-6.

32. Ramli, M.A.M.; Bouchekara, H.R.E.H.; Alghamdi, A.S. Optimal sizing of PV/wind/diesel hybrid microgrid system using multi-objective self-adaptive differential evolution algorithm. Renew. Energy 2018, 121, 400-411. [CrossRef]

33. Khooban, M.H.; Niknam, T.; Blaabjerg, F.; Davari, P.; Dragicevic, T. A robust adaptive load frequency control for micro-grids. ISA Trans. 2016, 65, 220-229. [CrossRef]

34. Shabani, H.; Vahidi, B.; Ebrahimpour, M. A robust PID controller based on imperialist competitive algorithm for load-frequency control of power systems. ISA Trans. 2013, 52, 88-95. [CrossRef]

35. Padhan, D.G.; Majhi, S. A new control scheme for PID load frequency controller of single-area and multi-area power systems. ISA Trans. 2013, 52, 242-251. [CrossRef]

36. Zamani, A.; Barakati, S.M.; Yousofi-Darmian, S. Design of a fractional order PID controller using GBMO algorithm for load-frequency control with governor saturation consideration. ISA Trans. 2016, 64, 55-66. [CrossRef]

37. Zheng, A.; Zhou, J.; Xu, Y.; Zhang, Y.; Qian, Z. A distributed model predictive control based load frequency control scheme for multi-area interconnected power system using discrete-time Laguerre functions. ISA Trans. 2017, 68, 127-140. [CrossRef]

38. Ali, S.; Yang, G.; Huang, C. Performance optimization of linear active disturbance rejection control approach by modified bat inspired algorithm for single area load frequency control concerning high wind power penetration. ISA Trans. 2018, 81, 163-176. [CrossRef]

39. Gampa, S.R.; Das, D. Real power and frequency control of a small isolated power system. Int. J. Electr. Power Energy Syst. 2015, 64, 221-232. [CrossRef]

40. Pan, I.; Das, S. Kriging Based Surrogate Modeling for Fractional Order Control of Microgrids. IEEE Trans. Smart Grid 2015, 6, 36-44. [CrossRef]

41. Ribeiro, P.; Johnson, B.; Crow, M.; Arsoy, A.; Liu, Y. Energy Storage Systems for Advanced Power Applications. Proc. IEEE 2001, 89, 1744-1756. [CrossRef]

42. Antony, A.P.; Shaw, D.T. Empowering the electric grid: Can SMES coupled to wind turbines improve grid stability? Renew. Energy 2016, 89, 224-230. [CrossRef]

43. Schainker, R. Executive Overview: Energy Storage Options for a Sustainable Energy Future. In Proceedings of the IEEE Power Engineering Society General Meeting, Denver, CO, USA, 6-10 June 2004.

44. Sadollah, A.; Bahreininejad, A.; Eskandar, H.; Hamdi, M. Mine blast algorithm for optimization of truss structures with discrete variables. Comput. Struct. 2012, 10, 49-63. [CrossRef]

45. Sadollah, A.; Bahreininejad, A.; Eskandar, H.; Hamdi, M. Mine blast algorithm: A new population based algorithm for solving constrained engineering optimization problems. Appl. Soft Comput. 2013, 13, 2592-2612. [CrossRef]

46. Sadollah, A.; Eskandar, H.; Bahreininejada, A.; Kim, J.H. Water cycle, Mine blast and improved mine blast algorithms for discrete sizing optimization of truss structures. Comput. Struct. 2015, 149, 1-16. [CrossRef]

47. Fathy, A. A reliable methodology based on mine blast optimization algorithm for optimal sizing of hybrid PV-wind-FC system for remote area in Egypt. Renew. Energy 2016, 95, 367-380. [CrossRef]

48. Sadollah, A.; Yoo, D.G.; Kim, J.H. Improved mine blast algorithm for optimal cost design of water distribution systems. Eng. Optim. 2014, 47, 1602-1618. [CrossRef]

49. Fathy, A.; Rezk, H. A novel methodology for simulating maximum power point trackers using mine blast optimization and teaching learning based optimization algorithms for partially shaded photovoltaic system. J. Renew. Sustain. Energy 2016, 8, 023503. [CrossRef]

50. Ramadan, H.S.; Fathy, A.; Becherif, M. Optimal gain scheduling of VSC-HVDC system sliding mode control via artificial bee colony and mine blast algorithms. IET Gener. Transm. Distrib. 2018, 12, 661-669.

51. Fathy, A.; Kassem, A.M.; Abdelaziz, A.Y. Optimal design of fuzzy PID controller for deregulated LFC of multiarea power system via mine blast algorithm. Comput. Appl. 2018, 1-21. [CrossRef]

52. Fathy, A.; El-baksawi, O. PI Controller Parameters Design of Doubly Fed Induction Generator Based on Mine Blast Algorithm. In Proceedings of the IEEE International Conference on Power and Energy (PECON), Melaka City, Malaysia, 28-30 November 2016; pp. 740-745. 
53. Lotfy, M.E.; Senjyu, T.; Abdel-Fattah; Farahat, M.; Abdel-Gawad, A.F.; Yona, A. Enhancement of a Small Power System Performance Using Multi-Objective Optimization. IEEE Access 2017, 5, 6212-6224. [CrossRef]

54. Das, D.; Adityaa, S.; Kothari, D. Dynamics of Diesel and Wind Turbine Generators on an Isolated Power System. International. J. Electr. Power Energy Syst. 1999, 21, 183-189. [CrossRef]

55. Abdeldjalil, D.; Nasreddine, N.S.; Mohamed-said, N.S. A novel combined MPPT-pitch angle control for wide range variable speed wind turbine based on neural network. Int. J. Hydrogen Energy 2016, 41, 9427-9442.

56. Mitani, Y.; Tsuji, K.; Murakami, Y. Application of Superconducting Magnet Energy Storage to Improve Power System Dynamic Performance. IEEE Trans. Power Syst. 1988, 3, 1418-1425. [CrossRef]

(C) 2019 by the authors. Licensee MDPI, Basel, Switzerland. This article is an open access article distributed under the terms and conditions of the Creative Commons Attribution (CC BY) license (http://creativecommons.org/licenses/by/4.0/). 